\title{
Spatial and Temporal Variability of Carbonaceous Aerosol Absorption in the Po Valley
}

\author{
Stefania Gilardoni ${ }^{1 *}$, Paola Massoli ${ }^{2 * \dagger}$, Angela Marinoni ${ }^{3}$, Claudio Mazzoleni ${ }^{4}$, \\ Andrew Freedman ${ }^{2}$, Giovanni Lonati ${ }^{5}$, Silvana De Iuliis ${ }^{6}$, Vorne Gianelle ${ }^{7}$
}

\author{
${ }^{1}$ Institute of Polar Sciences, CNR-ISP, 40129 Bologna, Italy \\ ${ }^{2}$ Aerodyne Research Inc., Billerica, MA 01821, USA \\ ${ }^{3}$ Institute of Atmospheric Sciences and Climate, CNR-ISAC, 40129 Bologna, Italy \\ ${ }^{4}$ Department of Physics and Atmospheric Sciences Program, Michigan Technological University, Houghton, MI 49931, \\ USA \\ ${ }^{5}$ Department of Civil and Environmental Engineering, Politecnico di Milano, 20133 Milan, Italy \\ ${ }^{6}$ Institute of Condensed Matter Chemistry and Technologies for Energy, CNR-ICMATE, 20125 Milan, Italy \\ ${ }^{7}$ Agenzia Regionale per Protezione dell'Ambiente, Via Juvara, 20129 Milan, Italy
}

\begin{abstract}
Knowledge gaps in the optical properties of carbonaceous aerosols account for a significant fraction of the uncertainty of aerosol - light interactions in climate models. Both black carbon (BC) and brown carbon (BrC) can display a range of optical properties in ambient aerosol due to different sources and chemical transformation pathways. This study investigates the optical absorption properties of $\mathrm{BC}$ and $\mathrm{BrC}$ at an urban and a rural site in the Po Valley (Italy), a known European pollution hot spot. We observed spatial and seasonal variability of aerosol absorption coefficients, with the highest values measured in winter at the urban site of Milan $\left(12 \mathrm{Mm}^{-1}\right.$ on average) and the lowest values in summer at the rural site of Motta Visconti (3 $\mathrm{Mm}^{-1}$ on average). The average aerosol Absorption Ångström Exponent (AAE) measured during the two experiments across the 370-880 nm wavelength range was 1.1 and 1.2 at the urban and the rural site, respectively. The observed AAE values in winter (the average AAE during the two winter campaigns was 1.2) are consistent with the contribution of wood burning $\mathrm{BrC}$, as confirmed by macro-tracer analysis. The $\mathrm{BC}$ mass absorption cross section (MAC $\mathrm{BC}_{\mathrm{B}}$ ) did not show a specific seasonal or spatial variability across the two sites and maintained an average value of $10 \pm 5 \mathrm{~m}^{2} \mathrm{~g}^{-1}$ at $880 \mathrm{~nm}$. The optical properties of $\mathrm{BrC}$, investigated off-line after extraction of organic aerosol (OA) indicate that wood burning was the dominant $\mathrm{BrC}$ source in winter, while secondary organic aerosol (SOA) from other anthropogenic emissions was the main source of $\mathrm{BrC}$ in summer.
\end{abstract}

Keywords: Black carbon; Brown carbon; Optical properties; Mass absorption cross section; Climate change.

\section{INTRODUCTION}

Carbonaceous aerosol accounts for more than half of fine atmospheric aerosol mass in urban, rural, and remote locations (Zhang et al., 2007; Bond et al., 2013). An accurate determination of the optical properties (absorption and scattering) and atmospheric concentrations of carbonaceous aerosol is necessary to improve the ability of climate models to describe the interactions of solar radiation with aerosol

\footnotetext{
$\dagger$ Now at Green Energy Consumers Alliance, Boston, MA, 02130, USA

${ }^{*}$ Corresponding author.

E-mail address: stefania.gilardoni@cnr.it
}

particles, and thus reduce the uncertainties in climate predictions (IPCC, 2013). Light absorbing carbonaceous aerosol components are identified as black carbon (BC) and brown carbon (BrC) (Andreae and Gelencser, 2006). BC is a known key atmospheric pollutant whose reduction is necessary in order to limit global warming (IPCC, 2018). BC has unique properties due to its refractory nature: it strongly absorbs visible light, is insoluble in water and organic solvents, and is made of aggregates of small carbon spherules with a high carbon to hydrogen ratio (Chakrabarty et al., 2006; Bond et al., 2013; Buseck et al., 2014). The absorption of BC per unit mass, also called the mass absorption cross section $\left(\mathrm{MAC}_{\mathrm{BC}}\right)$, is the highest among all the light absorbing aerosol species, with values larger than $5 \mathrm{~m}^{2} \mathrm{~g}^{-1}$ at $550 \mathrm{~nm}$ and centered around $7.5 \pm 1.2 \mathrm{~m}^{2} \mathrm{~g}^{-1}$ (Bond and Bergstrom 2006; Cross et al., 2010; Bond et al., 2013; Forestieri et al., 2018; Li et al., 2020). BC radiative forcing values used in 
models range between +0.05 and $+0.8 \mathrm{~W} \mathrm{~m}^{-2}$, while satellite and ground-based observations point towards higher values $\left(+0.7\right.$ to $\left.+0.9 \mathrm{~W} \mathrm{~m}^{-2}\right)$ (Bond et al., 2013). Part of the discrepancy between the radiative forcing estimated by models and observations is attributed to the variability of $\mathrm{MAC}_{\mathrm{BC}}$, which depends on intra-particle $\mathrm{BC}$ mixing state and particle morphology (China et al., 2013; China et al., 2015; Bhandari et al., 2019). The intra-particle mixing of $\mathrm{BC}$ particles with other material can lead to the enhancement of the $\mathrm{BC}$ absorption cross section and therefore of $\mathrm{MAC}_{\mathrm{BC}}$ (Lack et al., 2009). $\mathrm{MAC}_{\mathrm{BC}}$ enhancements observed in laboratory experiments vary from 2 to 3.5 (Zhang et al., 2008; Cross et al., 2010; Shiraiwa et al., 2010; Bond et al., 2013; Saliba et al., 2016), while field observations are characterized by a larger variability that is difficult to incorporate in models (Gustafsson and Ramanathan, 2016). Cappa et al. (2012) observed that aerosol aging in two California regions increased $\mathrm{MAC}_{\mathrm{BC}}$ by only about $6 \%$, while Moffet and Prather (2009) determined a $\mathrm{MAC}_{\mathrm{BC}}$ enhancement for aged soot in Mexico of $60 \%$. Peng et al. (2016) observed that $\mathrm{MAC}_{\mathrm{BC}}$ can be enhanced by 2.4 times, over timescales that differ significantly from clean to polluted environments, potentially explaining the field observation variability. Liu et al. (2015) reported lower enhancement factors (up to 1.5) consistent with Cappa et al. (2012). Discrepancies among laboratory and field observations are also due to the heterogeneity of particle ensemble composition (particle-toparticle differences) and the inaccurate assumption of spherical concentric core-shell structure (Fierce et al., 2020). Limited comparability among measurement techniques contributes to the variability of observed BC optical properties as well (Subramanian et al., 2007; Lack et al., 2008; Moosmuller et al., 2009).

More recently, part of the discrepancy between modeled and observed aerosol radiative forcing has been attributed to the presence of $\mathrm{BrC}$ in aerosols (Park et al., 2010; Feng et al., 2013; Jo et al., 2016; Chakrabarty et al., 2018). BrC is a mixture of organic species with different chemical identities, able to absorb both UV and visible light but with a stronger wavelength dependency than $\mathrm{BC}$, although characterized by a lower MAC (Bond et al., 2013). Unlike BC, BrC is mostly soluble in organic solvents (Chen and Bond, 2010). BrC contributes to primary and secondary organic aerosol (POA and SOA, respectively) originating from a variety of sources and chemical transformation pathways (Laskin et al., 2015; Moise et al., 2015). For example, recent studies indicate that tar balls from biomass burning contribute to atmospheric BrC through atmospheric aging (Chakrabarty et al., 2010; Sedlacek et al., 2018; Bhandari et al., 2019b). Despite the radiative forcing of $\mathrm{BrC}$ is highly uncertain, the impact of $\mathrm{BrC}$ on climate will likely increase in the future due to increase of wildfire frequency (Brown et al., 2018; Saturno et al., 2018; Jia et al., 2019).

Ground-based measurements indicate that $\mathrm{BrC}$ can account for up to $20 \%$ of carbonaceous aerosol light absorption between 400 and $600 \mathrm{~nm}$ (Chung et al., 2012b), although the larger concentrations of $\mathrm{BrC}$ at higher altitude can further increase BrC relative absorption (Feng et al., 2013; Zhang et al., 2017). Barnard et al. (2008) indeed estimated that $\mathrm{BrC}$ contributes up to $40 \%$ of top of the atmosphere aerosol absorption at wavelengths below $500 \mathrm{~nm}$. A limited number of studies using modeling and vertical profile observations indicate that $\mathrm{BrC}$ radiative forcing is equal to $+0.25 \mathrm{~W} \mathrm{~m}^{-2}$, thus partially offsetting the cooling effect of non-absorbing OA (Chung et al., 2012b; Feng et al., 2013). Nevertheless, the scarcity of ambient BrC optical property measurements make its representation in most chemistry and climate models difficult (Forrister et al., 2015; Sumlin et al., 2017; Tsigaridis and Kanakidou, 2018; Browne et al., 2019).

This study investigates the optical properties of BC and $\mathrm{BrC}$ in the Po Valley (Italy), one of the European pollution hot-spots. Bordered by the Alps to the north and by the Apennines to the south, the Po Valley is often subject to stagnant atmospheric conditions that favor the accumulation of atmospheric pollutants (Larsen et al., 2012). Across the Po Valley, wood burning for residential heating accounts for up to $50 \%$ of primary and secondary carbonaceous aerosol in wintertime (Gilardoni et al., 2011, 2014, 2016). In summer, the intense photochemical activity increases the concentration of SOA over freshly-emitted POA and BC (Saarikoski et al., 2012). Therefore, we can expect different concentrations of $\mathrm{BC}$ and $\mathrm{BrC}$ across the seasons. These conditions make the area an ideal site to extract the optical properties of $\mathrm{BC}$ and $\mathrm{BrC}$ and to investigate the effects of atmospheric aging on the optical properties of carbonaceous aerosol in the region.

\section{METHODS}

\section{Sampling Sites}

Aerosol optical properties and chemical composition were investigated at an urban site in Milan (MI, $45^{\circ} 28^{\prime} 43^{\prime \prime} \mathrm{N}$ $\left.9^{\circ} 13^{\prime} 56^{\prime \prime} \mathrm{E}\right)$ and at a rural site in the village of Motta Visconti (MV, 4516'55' 'N 8'59'19''E), about $30 \mathrm{~km}$ south-west of Milan. Milan has a population of about 1.3 million people and the sampling site, located inside the university campus, is representative of urban background conditions. Motta Visconti is a small village (population less than 10.000 inhabitants) surrounded by rice and corn fields. Both sites are in the greater Milan metropolitan area and are part of the air quality monitoring network of the Lombardy Environmental Protection Agency (ARPA Lombardia).

The historical emission inventory of the Milan metropolitan area shows that the main sources of BC and OA are road transport (76\% of $\mathrm{BC}$ and $23 \%$ of primary organic carbon, OC) and residential heating (12\% of BC and $49 \%$ of primary OC) (Inemar, 2014). Diesel cars account for $92 \%$ of BC emissions from the road transport sector (Inemar, 2014).

Table 1 reports the sampling periods at each site, covering winter and summer. Meteorological parameters measured during the four experiments are reported in Fig. S1. Wind speed was below $2 \mathrm{~m} \mathrm{~s}^{-1}$ most of the time, indicating low horizontal dispersion. Average temperature was $7{ }^{\circ} \mathrm{C}$ during winter and $19^{\circ} \mathrm{C}$ in summer. Relative humidity $(\mathrm{RH})$ was generally high with mean values above $70 \%$ both during summer and winter.

\section{On-line Optical Measurements}

Table 1 lists the instruments used for monitoring the 
Table 1. List of aerosol optical properties instruments used during the four experiments.

\begin{tabular}{|c|c|c|c|c|c|}
\hline Site & Season & Start & Stop & Instruments & Properties \\
\hline Milan (urban) & Winter & $02 / 05 / 16$ & $02 / 19 / 16$ & $\begin{array}{l}\text { Nephelometer M9003 }(545 \mathrm{~nm}) \\
\text { Aethalometer AE22 } 2(370,880 \mathrm{~nm}) \\
\text { MAAP }(670 \mathrm{~nm})\end{array}$ & $\begin{array}{l}\text { Scattering } \\
\text { Attenuation } \\
\text { Absorption }\end{array}$ \\
\hline $\begin{array}{l}\text { Motta Visconti } \\
\text { (rural) }\end{array}$ & Winter & $02 / 23 / 16$ & 03/06/16 & $\begin{array}{l}\text { Nephelometer AURORA } 3000(450,535 \text {, } \\
635 \mathrm{~nm}) \\
\text { Aethalometer AE22 } 2(370,880 \mathrm{~nm})\end{array}$ & $\begin{array}{l}\text { Scattering } \\
\text { Attenuation }\end{array}$ \\
\hline Milan (urban) & Summer & $06 / 01 / 16$ & $06 / 24 / 16$ & $\begin{array}{l}\text { Nephelometer M9003 }(545 \mathrm{~nm}) \\
\text { Aethalometer AE22 } 2(370,880 \mathrm{~nm}) \\
\text { MAAP }(670 \mathrm{~nm}) \\
\text { CAPS }(630 \mathrm{~nm})\end{array}$ & $\begin{array}{l}\text { Scattering } \\
\text { Attenuation } \\
\text { Absorption } \\
\text { Scattering and extinction }\end{array}$ \\
\hline $\begin{array}{l}\text { Motta Visconti } \\
\text { (rural) }\end{array}$ & Summer & 05/16/16 & $05 / 30 / 16$ & $\begin{array}{l}\text { Nephelometer M9003 }(545 \mathrm{~nm}) \\
\text { Aethalometer AE22 } 2(370 \mathrm{~nm}, 880 \mathrm{~nm})\end{array}$ & $\begin{array}{l}\text { Scattering } \\
\text { Attenuation }\end{array}$ \\
\hline
\end{tabular}

aerosol optical properties during the field observations at both sites. Throughout the four experiments, the aerosol light attenuation coefficient was measured at $880 \mathrm{~nm}$ and $370 \mathrm{~nm}$ with a 5-minute time resolution using an aethalometer AE22 (Magee Scientific) equipped with a $\mathrm{PM}_{10}$ head. The aethalometer operated at a flow rate of $4 \mathrm{~L} \mathrm{~min}^{-1}$ and filter tape advanced when absorbance at $370 \mathrm{~nm}$ reached the limit of 0.65 .

Aerosol light scattering was measured at 1-minute time resolution, using a $532 \mathrm{~nm}$ integrating nephelometer Ecotech M9003, with the exception of the rural winter experiment, when we employed a Ecotech AURORA 3000 operating at three wavelengths $(450 \mathrm{~nm}, 535 \mathrm{~nm}, 635 \mathrm{~nm})$. Nephelometers were calibrated using filtered air as zero span and $\mathrm{CO}_{2}$ as high span, in order to derive the calibration curve applied for scattering coefficient calculated by the instruments. The nephelometers sampled without any size cut. However, previous measurements indicate that the majority of aerosols at both sites is in the submicron fraction (Lonati et al., 2011 and Fig. S4). Although the presence of a small number of larger particles could have a significant impact on nephelometer observations, scattering coefficient data were employed mainly for attenuation measurement correction, with negligible effect on particle absorption in this study.

The M9003 measurements were not corrected for truncation error, in accordance with the manufacturer's indications. Indeed, Müller et al. (2009) demonstrated that, due to a fortuitous interaction of truncation and non-ideal angular illumination, the truncation correction is considered negligible for the typical urban particle size distribution. Concerning the Ecotech AURORA 3000, we applied a truncation correction coefficient for total scattering ranging between 1.006 and 1.106 (mean value 1.050) using the Scattering Angström Exponent (SAE) and the algorithm developed by Müller $e t$ al. (2011). The correction coefficient close to one is consistent with the particle number size distribution being dominated by submicron particles.

During the summer experiment at the Milan urban site, we employed a Cavity Attenuated Phase Shift (CAPS) PM SSA monitor (Aerodyne Inc., Billerica) that provides a fast-response measurement of both optical extinction and scattering coefficients of aerosol particles at $630 \mathrm{~nm}$ (Onasch et al., 2015). The aerosol was sampled through a line equipped with $\mathrm{PM}_{10}$ size cut. The ratio of scattering to total extinction, i.e., the single scattering albedo (SSA), was calculated at 1second time resolution. The scattering channel, which derives its data from a reverse nephelometer incorporated into the extinction measurement cell, was calibrated using polystyrene latex spheres at the beginning of the experiment, and filtered air baseline values were recorded for 45 seconds every 10 minutes for zeroing purposes. The extinction coefficients measured by the monitor are estimated to have an accuracy of $\pm 5 \%$. In the small particle limit ( $<250 \mathrm{~nm}$ diameter), the SSA values are accurate within \pm 0.01 ; however, particle size distributions previously collected at the same location indicate that the accumulation particle mode at the Milan urban site has a geometric mean diameter of about $250 \mathrm{~nm}$ and a geometric standard deviation of about 2 (Lonati et al., 2011), corresponding to a CAPS truncation error of 1.04 (Onasch et al., 2015) which was applied to the CAPS data. After applying the truncation error correction, the absorption values were calculated by multiplying the measured extinction by the co-albedo (1-SSA).

In addition, particle light absorption at $670 \mathrm{~nm}$ was measured at 15-minute time resolution with a Multi-Angle Absorption Photometer (MAAP 5012 Thermo Fisher) equipped with a $\mathrm{PM}_{10}$ sampling head at the urban site, both in winter and summer.

\section{Aethalometer-based Absorption Coefficients}

The aethalometer attenuation coefficients $\left(b_{\mathrm{ATN}}\right)$ and the nephelometer scattering coefficient $\left(b_{\text {scat }}\right)$ were combined to calculate the absorption coefficient $\left(b_{a b s}\right)$ according to the correction algorithm developed by Collaud-Coen et al. (2010).

$b_{a b s}(\lambda)=\frac{b_{A T N}(\lambda)-\alpha b_{s c a t}(\lambda)}{\mathrm{R} C_{r e f}}$

$\mathrm{b}_{\mathrm{abs}}$ is the absorption coefficient at a given wavelength $(\lambda)$, while $\alpha, \mathrm{R}$, and $\mathrm{C}_{\text {ref }}$ are correction coefficients considering light scattered by particles on the aethalometer filter tape, filter loading, and multiple scattering, respectively.

It is known that particles deposited on the aethalometer filter tape and able to scatter the instrument beam light decrease the intensity of light reaching the detector, leading 
to an overestimation of aerosol light absorption (Arnot et al., 2005) The scattering artifact is quantified by the $\alpha$, which depends on the particle scattering coefficient. During the experiment, $\alpha$ was on the order of $10^{-5}$, and the overestimation of $b_{a b s}$ due to scattering was negligible (below $0.01 \%$ ).

At the same time, the accumulation of absorbing particles on the filter tape might prevent some particles from absorbing incident light beam, underestimating the actual aerosol absorption. The filter loading correction is introduced by the term R, which depends on the filter attenuation (ATN) and on the particle's SSA. For the n-th measurement over the s-th filter spot, $\mathrm{R}_{\mathrm{n}, \mathrm{s}}$ is given by:

$$
R_{n, s}=\left(\frac{1}{0.74\left(1-\bar{\omega}_{0 n, s}\right)}-1\right) \frac{A T N_{n}}{50}+1
$$

where $\mathrm{ATN}_{\mathrm{n}}$ is the percentage attenuation, and $\bar{\omega}_{0 . s}$ is the mean SSA measured over the s-th filter spot. A first estimate of $\bar{\omega}_{0 n . s}$ is calculated by combining the scattering coefficient measured by the nephelometer and the attenuation coefficient. During the experiments, $\mathrm{R}$ ranged between 1 and 0.7 , indicating that the filter loading effect was significant. If neglected, this could have led to an underestimation of the absorption coefficient by up to $40 \%$ over a 15 -minute time period (Supplementary material Fig. S2).

The $\mathrm{C}_{\text {ref }}$ coefficient corrects multiple light scattering artifacts occurring on the filter tape fibers that can lead to an absorption enhancement. We estimated $\mathrm{C}_{\text {ref }}$ by comparing the MAAP $b_{a b s}$ at $670 \mathrm{~nm}$ with the attenuation coefficient corrected for the loading effect and extrapolated at $670 \mathrm{~nm}$ using the aethalometer Absorption Angström Exponent (AAE), which describes the wavelength dependence of light absorption. The resulting $\mathrm{C}_{\text {ref }}$ was 2.5 in summer and 3.0 in winter, and compared well with the values reported in Collaud-Coen et al. (2010) for aerosol samples with SSA larger than 0.8 (2.5-3.6), as well as with the average of 3.5 observed at several European ACTRIS sites (Muller, personal communication). $\mathrm{C}_{\mathrm{ref}}$ is affected by the aerosol type. For example, liquid organic phase, which redistributes on filter fibers, modifies the $\mathrm{C}_{\text {ref }}$ value (Lack et al., 2008). In addition, $\mathrm{C}_{\text {ref }}$ depends on aerosol single scattering albedo (SSA) and on wavelength (Weingartner et al., 2003; Collaud-Coen et al., 2010). The lack of reference absorption measurements at different wavelengths did not allow a determination of $\mathrm{C}_{\mathrm{ref}}$ wavelength dependence, and the same $C_{\text {ref }}$ was used at 880 $\mathrm{nm}$ and $370 \mathrm{~nm}$. In addition, since no MAAP measurements were available at Motta Visconti, we used the $\mathrm{C}_{\text {ref }}$ calculated at the urban location. This was an acceptable compromise given the similar seasonal SSA values observed at the two sites, as reported in Table 2 .

\section{Off-line Optical and Chemical Measurements}

$\mathrm{PM}_{1}$ aerosol samples were collected daily during the four field experiments (from 00:00 to 23:59 local time) using an automated Tecora aerosol sampler operating at $1.15 \mathrm{~m}^{3} \mathrm{~h}^{-1}$. Samples were stored at $4^{\circ} \mathrm{C}$ prior to analysis. For each filter, a $1.5 \mathrm{~cm}^{2}$ punch was analysed to quantify organic carbon (OC) and elemental carbon (EC) concentration, by thermooptical technique, using NIOSH-Like heating protocol (Peterson and Richards, 2002). A second punch $\left(1 \mathrm{~cm}^{2}\right)$ was extracted with water and the solution was analysed by ion chromatography to quantify levoglucosan, a proxy for biomass burning. In addition, daily $\mathrm{PM}_{10}$ aerosol samples were collected routinely at the urban site to measure $\mathrm{PM}_{10}$ mass concentration and its chemical composition. OC and EC concentration were quantified with the same procedure employed for the analysis of $\mathrm{PM}_{1}$ carbonaceous fraction.

Finally, we quantified daily water-soluble and methanolsoluble $\mathrm{BrC}$ concentrations in $\mathrm{PM}_{1}$ aerosol samples. Two $1 \mathrm{~cm}^{2}$ punches were extracted in $5 \mathrm{~mL}$ of mQ water and $5 \mathrm{~mL}$ of HPLC grade methanol, respectively, by 30-minute ultrasonication. Solutions were then filtered, and the UVvisible light absorption spectra were recorded using a TIDAS E UV/visible light spectrometer (J\&M Analitik AG, Germany), equipped with a liquid waveguide capillary cell (LWCC-3050, $0.5 \mathrm{~m}$ long, World Precision Instruments, Sarasota, FL) in the range $300 \mathrm{~nm}-720 \mathrm{~nm}$. The absorption coefficient was then calculated according to the following equation:

Table 2. Average optical properties of carbonaceous aerosol observed during the four experiments; standard deviations are reported in brackets.

\begin{tabular}{|c|c|c|c|c|}
\hline Site & Milan Urban & Motta Visconti Rural & Milan Urban & Motta Visconti Rural \\
\hline Season & Winter & Winter & Summer & Summer \\
\hline \multicolumn{5}{|l|}{ Aerosol } \\
\hline $\mathrm{b}_{\mathrm{abs} 880}\left(\mathrm{Mm}^{-1}\right)$ & $12.1(8.5)$ & $7.6(7.1)$ & $6.2(4.1)$ & $3.3(2.4)$ \\
\hline $\mathrm{b}_{\mathrm{abs} 370}\left(\mathrm{Mm}^{-1}\right)$ & $38.8(27.6)$ & $28.7(30.1)$ & $18.1(13.9)$ & $9.6(6.3)$ \\
\hline $\mathrm{AAE}_{370-880}$ & $1.1(0.2)$ & $1.2(0.3)$ & $1.0(0.4)$ & $1.1(0.5)$ \\
\hline $\operatorname{MAC}_{\mathrm{EC}} 880\left(\mathrm{~m}^{2} \mathrm{~g}^{-1}\right)$ & $9.8(2.2)$ & $10.5(1.1)$ & $9.5(1.6)$ & $9.0(2.0)$ \\
\hline SSA & $0.72(0.15)$ & $0.76(0.12)$ & $0.67(0.15)$ & $0.68(0.17)$ \\
\hline \multicolumn{5}{|l|}{ Methanol-soluble BrC } \\
\hline $\mathrm{B}_{\text {abs } 370}\left(\mathrm{Mm}^{-1}\right)$ & $6.0(2.7)$ & $5.3(3.0)$ & $1.4(0.4)$ & $1.0(0.5)$ \\
\hline $\mathrm{AAE}_{330-500}$ & $3.3(0.3)$ & $3.6(0.4)$ & $2.7(0.2)$ & $3.1(0.5)$ \\
\hline $\operatorname{MAC} C_{\mathrm{BrC} 370}\left(\mathrm{~m}^{2} \mathrm{~g}^{-1}\right)$ & $1.2(0.2)$ & $1.2(0.3)$ & $0.5(0.1)$ & $0.3(0.1)$ \\
\hline \multicolumn{5}{|l|}{ Water-soluble BrC } \\
\hline $\mathrm{b}_{\mathrm{abs} 370}\left(\mathrm{Mm}^{-1}\right)$ & $3.0(1.3)$ & $2.4(1.0)$ & $0.5(0.2)$ & $0.5(0.2)$ \\
\hline $\mathrm{AAE}_{330-500}$ & $4.6(0.4)$ & $6.0(0.6)$ & $6.1(1.3)$ & $6.1(1.2)$ \\
\hline
\end{tabular}


$b_{a b s \lambda}=\left(A b s_{\lambda}-A b s_{700}\right) \frac{V_{l}}{V_{a} l} \ln (10)$

where $\mathrm{Abs}_{\lambda}-\mathrm{Abs}_{700}$ is the absorbance at $\lambda$ corrected for any drift using as reference the absorbance at $700 \mathrm{~nm}, \mathrm{~V}_{\mathrm{a}}$ is the volume of sampled air, $\mathrm{V}_{1}$ is the extraction solvent volume, and 1 is the optical length of the LWCC cell (Hecobian et al., 2010).

\section{RESULTS AND DISCUSSION}

\section{Aerosol Optical Properties}

Fig. 1(a) compares the hourly averaged $b_{a b s}$ values at $630 \mathrm{~nm}$ obtained from the MAAP (adjusted to $630 \mathrm{~nm}$ using the aethalometer AAE) and from the CAPS PMssa (obtained by difference of extinction and scattering). The data points are color coded by SSA. While the technical principles of the two techniques differ substantially (the CAPS PM measures optical properties of particles suspended in the air, while the MAAP measurements are filter-based) the correlation coefficient between the datasets is equal to 0.97 and the slope is $0.95 \pm 0.01$. In addition, when isolating data points corresponding to SSA larger than 0.8 (a condition that can lead to sizeable errors in the $b_{a b s}$ values obtained by difference), we do not observe a statistically significant bias relative to the 1:1 line. Furthermore, the good agreement between the CAPS PM $\mathrm{SSA}_{\mathrm{SA}}$ and MAAP $\mathrm{b}_{\mathrm{abs}}$ values suggests that the effects related to the absorption of gas-phase species on the filter and subsequent coating of the filter fibers (Lack et al., 2007; Subramanian et al., 2007), as well as multiple scattering artifacts (Nakayama et al., 2010), can be considered negligible during the present study.

Fig. 1(b) compares the $b_{a b s}$ estimated from aethalometer measurements at the urban site with the $b_{a b s}$ from the MAAP, both in summer and winter. Data are adjusted to $880 \mathrm{~nm}$ using the aethalometer AAE. We observed a good agreement between the data obtained from the two techniques, with residuals centered around zero and a standard deviation smaller than $20 \%$. The results confirm the validity of the procedure used in this study to derive the absorption coefficient from aethalometer attenuation measurements, and suggest that the aethalometer correction algorithm is precise.

The box-whisker plots in Fig. 2 show the aethalometer $b_{\text {abs }}$ at $880 \mathrm{~nm}$ (panel a) and $370 \mathrm{~nm}$ (panel b) measured during the four experiments in Milan (MI) and Motta Visconti (MV), grouped by season (winter in blue and summer in red). The plots report the $b_{a b s}$, while average absorption coefficients at $880 \mathrm{~nm}$ and $370 \mathrm{~nm}$, together with their standard deviations, are reported in Table 2 . Higher $b_{\text {abs }}$ values were observed in winter at both sampling sites, likely due to the combined effect of higher emissions of light-absorbing species from residential heating and accumulation of pollutants near the surface due to the frequent atmospheric inversion conditions. In addition, during that particular winter, low wind speed and a small number of rain events limit pollutant dispersion and wet removal. Overall, higher $b_{\text {abs }}$ values were observed at the urban site of Milan independently on the season, indicating a stronger contribution of $\mathrm{BC}$ to the urban light-absorbing aerosols.

Fig. 2(c) shows the AAE during the four experiments. The AAE in the UV - IR range is calculated from the $b_{a b s}$ coefficients at 370 and $880 \mathrm{~nm}$ :

$$
A A E=-\frac{\ln \frac{b_{a b s} 880}{b_{a b s} 370}}{\ln \frac{880}{370}}
$$

The average AAE was 1.1 and 1.0 at the urban site and 1.2 and 1.1 at the rural site, in winter and summer, respectively. Assuming that 1.1 is an upper bound for $\mathrm{AAE}_{\mathrm{BC}}$ (see section "Brown carbon measurements"), our observations of AAE values larger than 1.1 in most of the winter data $(58 \%$ and $71 \%$ of data points in Milan and Motta Visconti, respectively) indicate a consistent presence of $\mathrm{BrC}$ in the air samples, especially at the rural site, where AAE values are higher.

Using the average AAE and Eq. (4), we adjusted the $b_{a b s}$ measured during this study to different wavelengths to compare with literature values. Both the absorption coefficient values measured in Milan and their seasonal variation are comparable to those observed at other southern European a)

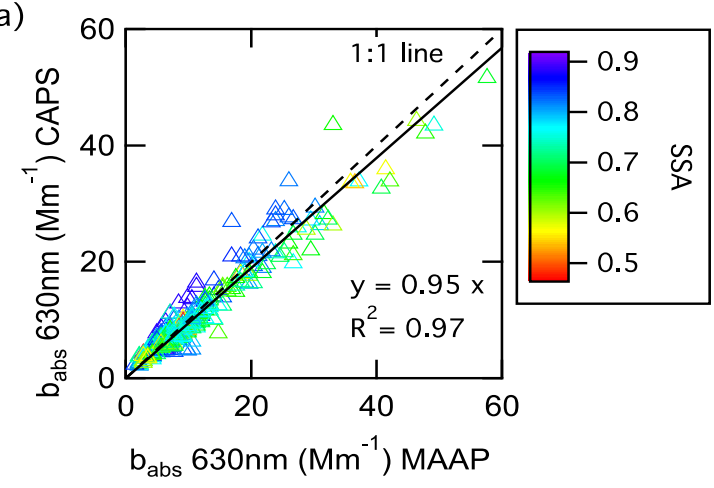

b)

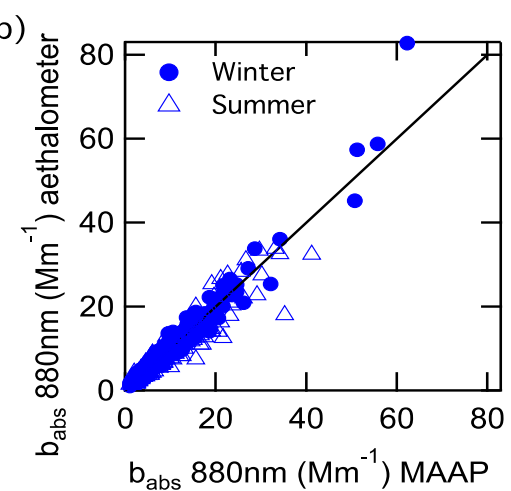

Fig. 1. Comparison of absorption coefficients at $630 \mathrm{~nm}$ from CAPS PM $\mathrm{MSA}_{\mathrm{SS}}$ and MAAP measurements (panel a); markers are color-coded as a function of SSA measured by the CAPS PMSSA. Panel b compares absorption coefficients estimated form aethalometer through the described correction algorithm with the MAAP absorption data, adjusted at $880 \mathrm{~nm}$ in summer (triangles) and winter (circles). Measurements here reported were performed at the urban site. 

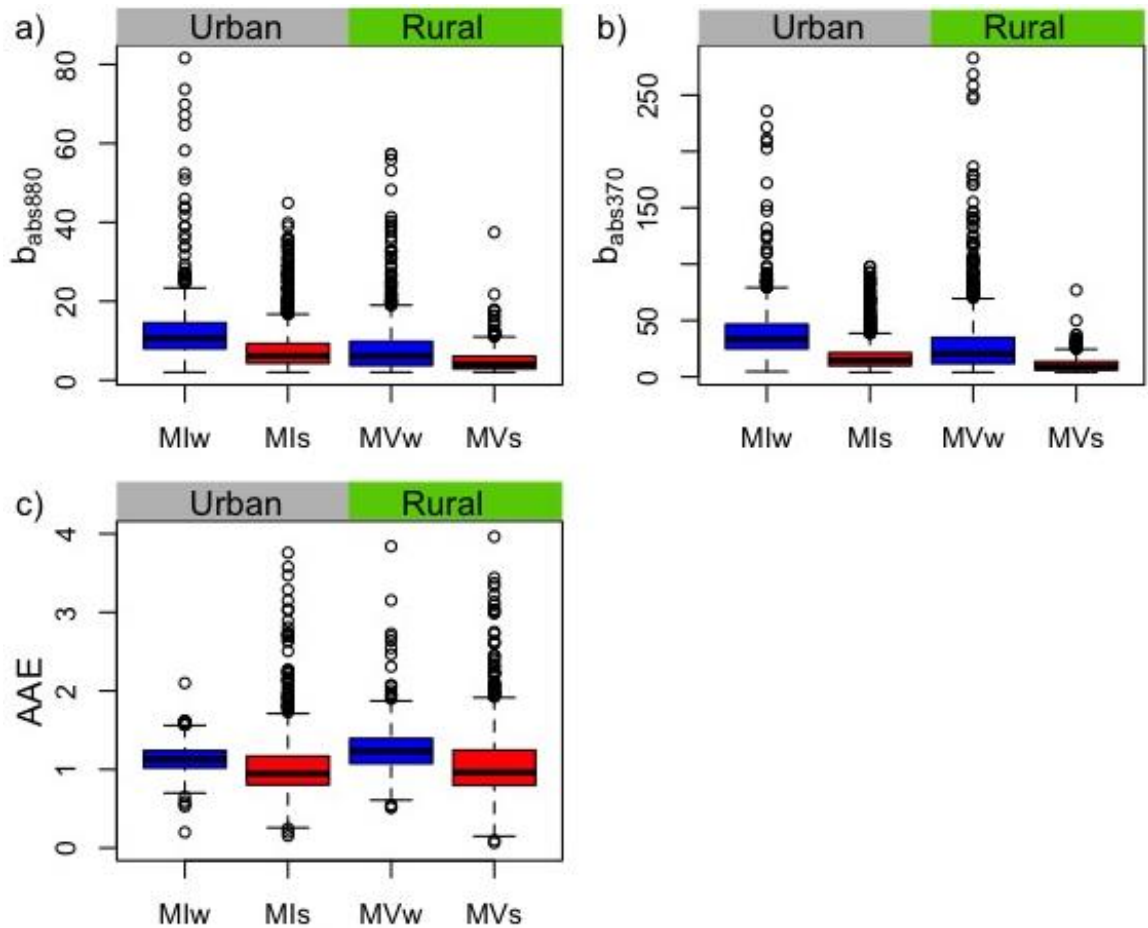

Fig. 2. Box-whisker plots showing the variability of absorption coefficients at $880 \mathrm{~nm}$ (panel a), at $370 \mathrm{~nm}$ (panel b) and Absorption Ångström Exponent (AAE panel c) derived from aethalometer measurements in Milan in winter and summer (MIw and MIs, respectively) and in Motta Visconti in winter and summer (MVw and MVs, respectively).

urban sites. For example, the average $b_{a b s}$ at $637 \mathrm{~nm}$ in Rome in winter was $19 \mathrm{Mm}^{-1}$ (Costabile et al., 2017), while in Barcelona the monthly $b_{a b s}$ averages varied between $10 \mathrm{Mm}^{-1}$ (in summer) and $20 \mathrm{Mm}^{-1}$ (in winter) (Ealo et al., 2018). These values compare well with the seasonal averages observed in Milan when adjusted to $637 \mathrm{~nm}$, i.e., 11 and $20 \mathrm{Mm}^{-1}$. Conversely, the average $b_{a b s}$ at Motta Visconti at $637 \mathrm{~nm}(7$ and $14 \mathrm{Mm}^{-1}$ in summer and winter, respectively) are higher than typical southern European rural coefficients $\left(2-4 \mathrm{Mm}^{-1}\right)$ (Zanatta et al., 2016; Ealo et al., 2018). These results confirm the conclusions of a previous study reporting small differences between urban and rural sites in the Po Valley, and indicating that air masses are well-mixed in the basin (Sandrini et al., 2014).

\section{Black Carbon Optical Properties}

In order to characterize BC optical properties, this study uses EC from thermal-optical measurements as a proxy, even if $\mathrm{EC}$ and $\mathrm{BC}$ are not equivalent. In fact, BC typically refers to both refractory and non-refractory carbonaceous aerosol strongly absorbing across a wide part of the visible spectrum, while EC indicates only the refractory component of the carbonaceous aerosol (Bond and Bergstrom, 2006). In the $\mathrm{PM}_{1}$ size fraction, EC concentrations in Milan averaged 1.52 and $0.80 \mu \mathrm{g} \mathrm{m}^{-3}$, while in Motta Visconti averaged 0.92 and $0.48 \mu \mathrm{g} \mathrm{m}^{-3}$ in winter and summer, respectively. Higher EC concentrations were observed at the urban site, due to a larger contribution of anthropogenic combustion emissions from vehicular traffic both in winter and summer.

$\mathrm{MAC}_{\mathrm{EC}}$ (proxy for $\mathrm{MAC} \mathrm{BC}_{\mathrm{B}}$ ) is defined as the ratio between the daily average light absorption coefficient and the EC concentration from thermal-optical analysis of $\mathrm{PM}_{1}$ daily samples:

$$
M A C_{E C}=\frac{b_{a b s} 880}{E C}
$$

where the $b_{a b s}$ coefficients and EC measurements are obtained from instrument with two different size cuts $\left(\mathrm{PM}_{10}\right.$ and $\mathrm{PM}_{1}$ respectively). However, comparison between $\mathrm{PM}_{10}$ and $\mathrm{PM}_{1} \mathrm{EC}$ measurements at the urban site indicates that, on average, at least $90 \%$ of EC is contained in submicron particles (Fig. S3). In conclusion, the error introduced by neglecting the $10 \%$ mass fraction of EC larger than $1 \mathrm{~m}$ is likely within the uncertainty of EC measurements, typically estimated to be around $30 \%$ (Karanasiou et al., 2015). Further, we use the $b_{a b s}$ coefficients measured at $880 \mathrm{~nm}$ to remove potential interference from the $\mathrm{BrC}$ absorption at shorter wavelengths, and only days characterized by $b_{a b s}$ data availability larger than $70 \%$ are considered for this analysis.

The average $\mathrm{MAC}_{\mathrm{EC}}$ values for the four measurement periods and their confidence intervals, ( \pm standard deviation) obtained from Eq. (5) are reported in Table 2. MAC $\mathrm{EC}_{\mathrm{EC}}$ values were comparable across sites and seasons. Despite the short duration of the experiments, this result is consistent with previous observations that did not report any seasonal variation of EC optical properties in rural Europe across longer periods (Zanatta et al., 2016).

Furthermore, the $\mathrm{MAC}_{\mathrm{EC}}$ measured at Motta Visconti during this study falls in the range of values reported for other European rural background sites adjusted to $880 \mathrm{~nm}$, i.e., 5.7-16.4 $\mathrm{m}^{2} \mathrm{~g}^{-1}$ (Genberg et al., 2013, Zanatta et al., 2016). 
Similarly, the average $\mathrm{MAC}_{\mathrm{EC}}$ observed in Milan compares well with measurements in European urban sites, including Barcelona $\left(6.7 \mathrm{~m}^{2} \mathrm{~g}^{-1}\right.$ ) (Reche et al., 2011) and Paris (8$10 \mathrm{~m}^{2} \mathrm{~g}^{-1}$ at $950 \mathrm{~nm}$ ) (Sciare et al., 2011).

Given that the MAC of freshly generated soot ranges between 6.3 and $8.7 \mathrm{~m}^{2} \mathrm{~g}^{-1}$ at $550 \mathrm{~nm}$, or to 3.9 and $5.4 \mathrm{~m}^{2} \mathrm{~g}^{-1}$ at $880 \mathrm{~nm}$ (Bond and Bergstrom 2006), the higher MAC values observed during this and other ambient experiments are likely due to changes in $\mathrm{BC}$ optical properties with atmospheric aging, and possibly to intra-particle mixing configuration.

We investigated the effect of intra-particle mixing state on $\mathrm{BC}$ optical properties by looking at the variability of $\mathrm{MAC}_{\mathrm{EC}}$ as a function of the non-refractory $\mathrm{PM}_{1}$ to $\mathrm{EC}$ ratio $\left(\mathrm{PM}_{1 \mathrm{nr}} / \mathrm{EC}\right)$. The $\mathrm{PM}_{1 \mathrm{nr}} / \mathrm{EC}$ ratio can be used as a proxy for $\mathrm{BC}$ coating thickness. Zanatta et al. (2016) observed that, in most European sites reporting long term $\mathrm{BC}$ and $\mathrm{EC}$ measurements, $\mathrm{MAC}_{\mathrm{EC}}$ increases with the $\mathrm{PM}_{1 \mathrm{nr}} / \mathrm{EC}$ ratio, with different slopes depending on the location. Fig. 3 reports the measurements performed at the Milan urban site (Fig. 3, panel a) and at the Motta Visconti rural site (Fig. 3, panel b). In Milan, the $\mathrm{PM}_{1 \mathrm{n} /} / \mathrm{EC}$ ratio varies between 5 and 30 , while $\mathrm{MAC}_{\mathrm{EC}}$ varied by a factor of two, with values ranging from 6 and $12 \mathrm{~m}^{2} \mathrm{~g}^{-1}$. The lowest MAC $\mathrm{EC}_{\mathrm{E}}$ was $6.6 \mathrm{~m}^{2} \mathrm{~g}^{-1}$ and was observed on June 21. During that day, the site sampled $\mathrm{BC}$ particles emitted from a nearby fire clearly visible from the measurement site as a black smoke plume. It is reasonable to assume that $\mathrm{BC}$ particles sampled during such episode were fresh and not internally mixed, explaining the relatively low $\mathrm{MAC}_{\mathrm{EC}}$ compared to the $\mathrm{PM}_{1 \mathrm{nr}} / \mathrm{EC}$ ratio of 12 . The black dotted lines in Fig. 3 identify orthogonal regression lines of the measured data after removing the June 21 point. After excluding the local fire episode, the linear correlation agrees with observations reported at most European sites and indicates that the $\mathrm{PM}_{1 \mathrm{nr}} / \mathrm{EC}$ ratio explains $75 \%$ of the $\mathrm{MAC}_{\mathrm{EC}}$ variability observed in Milan. On the contrary, the correlation between $\mathrm{PM}_{1 \mathrm{nr}} / \mathrm{EC}$ and $\mathrm{MAC}_{\mathrm{EC}}$ at Motta Visconti was not statistically significant, with a Pearson coefficient of -0.02 . The difference in slope and correlation might be related to different intra-particle mixing configurations and the source variability. The variability of fuel type might affect morphology and mixing state of combustion-generated particles, which in turn modify their MAC (Bond et al., 2006), The variability of fuel type can also introduce a bias in the EC thermal-optical measurements (Cavalli et al., 2010), hampering the dependency of MAC on $\mathrm{PM}_{1 \mathrm{nr}} / \mathrm{EC}$ especially in a short lasting experiment. The rural measurement site is in an area characterized by intensive agricultural activities (rice fields) and we cannot exclude the impact of local combustion activities such as agricultural waste burning, mixing with urban outflow. Consistently, there was a larger variability range of the levoglucosan to $\mathrm{EC}$ ratio in winter (0.04-0.30) at Motta Visconti than in Milan (0.02-0.06) (levoglucosan concentration in summer was below detection limit during the investigated periods).

\section{Brown Carbon $(\mathrm{BrC})$ Measurements}

$\mathrm{BrC}$ light absorption at $370 \mathrm{~nm}\left(\mathrm{~b}_{\mathrm{abs} \mathrm{BrC} 370}\right)$ is determined from the aethalometer measurements, by subtracting the $\mathrm{BC}$ contributions according to the following equation:

$b_{a b s B r c 370}=b_{a b s 370}-b_{a b s 880}\left(\frac{880}{370}\right)^{A A E_{-} B C}$

This equation implies that the main species contributing to the absorption at $370 \mathrm{~nm}$ are $\mathrm{BC}$ and $\mathrm{BrC}$.

The use of Eq. (6) to obtain $b_{a b s} B r C 370$ requires an assumption about the choice of the $\mathrm{AAE}_{\mathrm{BC}}$ values, which are known to depend on $\mathrm{BC}$ particle size and their mixing state and to span a wide range. Based on the Mie-theory core-shell model (spherical particles), Lack and Cappa (2010) concluded that $\mathrm{BC}$ can show AAE values as high as 1.6, and that AAE smaller than 1.6 cannot exclude a $\mathrm{BrC}$ presence. $\mathrm{Li}$ et al. (2016) used numerical simulations to calculate the $\mathrm{AAE}_{\mathrm{BC}}$ variability range and reported values of $0.9-1.5$ for fractal aggregates, and 0.6-1.5 for spheres and spheroids. Conversely, ambient measurements of $\mathrm{AAE}_{\mathrm{BC}}$ performed with various methods point towards a narrower range. Chung et al. (2012b) estimated an AAE of 0.7-1 for BC and 1.6-1.8 for $\mathrm{BrC}$ between 350 and $970 \mathrm{~nm}$. Zotter et al. (2017) estimated the AAE of BC and wood burning particles (containing both BC and $\mathrm{BrC}$ ) comparing aethalometer data and radiocarbon
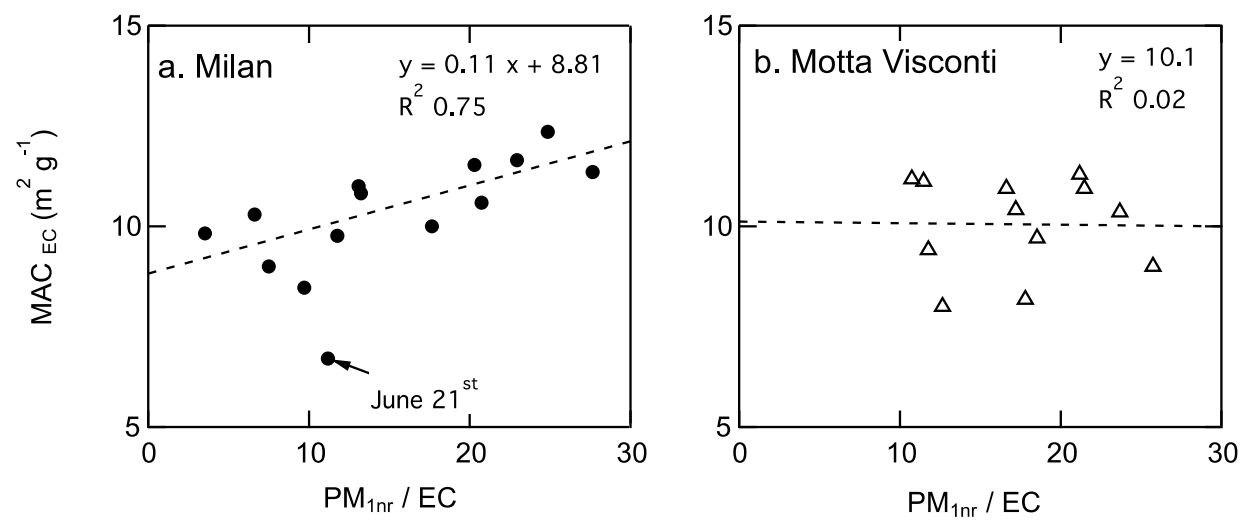

Fig. 3. Dependence of elemental carbon mass absorption cross section (MAC $\mathrm{EC}_{\mathrm{C}}$ ) on the non-refractory $\mathrm{PM}_{1}$ to elemental carbon ratio $\left(\mathrm{PM}_{1 \mathrm{nr}} / \mathrm{EC}\right)$, used as a proxy of soot particle coating, during the experiments in Milan (urban site, panel a) and Motta Visconti (rural site, panel b). 
measurements and concluded that the best estimate for $\mathrm{AAE}_{\mathrm{BC}}$ was 0.9 in the 470-950 $\mathrm{nm}$ range. Similarly, Martinsson et al. (2017) validated the assumption of $\mathrm{AAE}_{\mathrm{BC}}$ equal to unity using radiocarbon measurements. Laboratory experiment reported $\mathrm{AAE}_{\mathrm{BC}}$ of fresh fossil fuel burning emission between 0.8 and 1.1 (Kirchstetter 2004; Sharma et al., 2013; Yuan et al., 2016; Blanco-Alegre et al., 2020). Therefore, we used a range of $\mathrm{AAE}_{\mathrm{BC}}$ values collected during field and laboratory experiments $(0.7-1.1)$ and calculated a center value of $\mathrm{b}_{\mathrm{abs} B \mathrm{BrC}} 370$ using $\mathrm{AAE}_{\mathrm{BC}}$ equal to 0.9. Using literature $\mathrm{AAE}_{\mathrm{BC}}$ ambient and laboratory measurement range (Chung et al., 2012a; Martinsson et al., 2017; Zotter et al., 2017), we also calculated the upper and lower bounds of $b_{a b s ~} \operatorname{BrC} 370$ using $\mathrm{AAE}_{\mathrm{BC}}$ equal to 0.7 and 1.1, respectively.

Although Mie theory calculation might indicate that $\mathrm{AAE}_{\mathrm{BC}}$ can be larger than 1.1, it is worth noting that an $\mathrm{AAE}_{\mathrm{BC}}$ of 1.1 in this study would lead to many negative $\mathrm{Abs}_{\mathrm{BrC} 370}$ values, especially in summer $(83 \%$ and $98 \%$ of hourly data at Milan and Motta Visconti, respectively). This result would not be consistent with the off-line measurements indicating $\mathrm{BrC}$ presence during the summertime and wintertime experiments (Fig. 5). Therefore, an $\mathrm{AAE}_{\mathrm{BC}}$ equal to or higher than 1.1 is unlikely to represent the optical properties of $\mathrm{BC}$ in the Po valley.

Figs. 4(a) and 4(b) report the daily variation of the $\mathrm{BrC}$
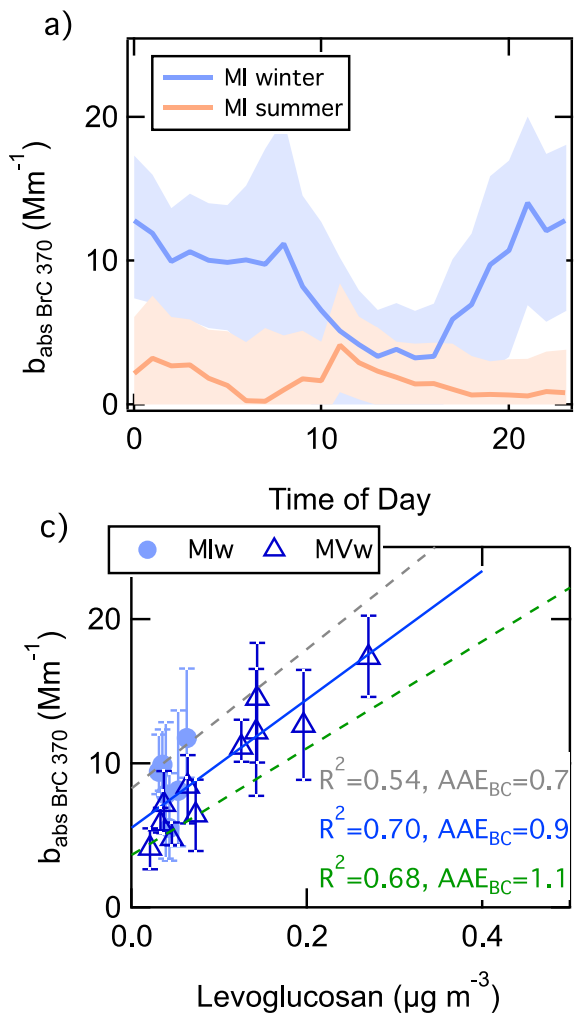

light absorption coefficient at $370 \mathrm{~nm}$ at the urban and rural site, respectively. The shadowed areas indicate the upper and lower bounds of $b_{a b s} B r C 370$ based on the different $A A E_{B C}$

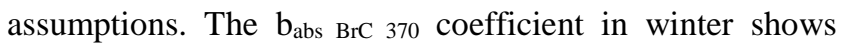
maxima during evening and night-time, in agreement with the typical diurnal trend of wood burning for residential heating, previously identified as one of the main sources of OA in the Po Valley (Gilardoni et al., 2014, 2016). Several studies indicate that primary and secondary wood burning OA contribute to aerosol light absorption in the UV and visible range (Habib et al., 2008; Hecobian et al., 2010; Saleh et al., 2014). Even though wood burning emissions are higher during the evening when stoves and fireplaces are used for residential heating, biomass burning OA remains high during the night and decreases during day-time due to the evolution of boundary layer height. Interestingly, the diurnal variation of the $\mathrm{b}_{\mathrm{abs} \mathrm{BrC}} 370$ coefficient in winter was similar at the urban and rural sites due to the similar evolution of the mixing layer, although the rural site showed higher $\mathrm{BrC}$ signals in the evening. Consistently, regional inventories in the urban settings (Inemar, 2014).

The rural site in summer was characterized by an increase in the $b_{\mathrm{abs} \mathrm{BrC} 370}$ during the central part of the day, when solar radiation was higher and the highest concentration of secondary OA is expected (Saarikoski et al., 2012). Ambient
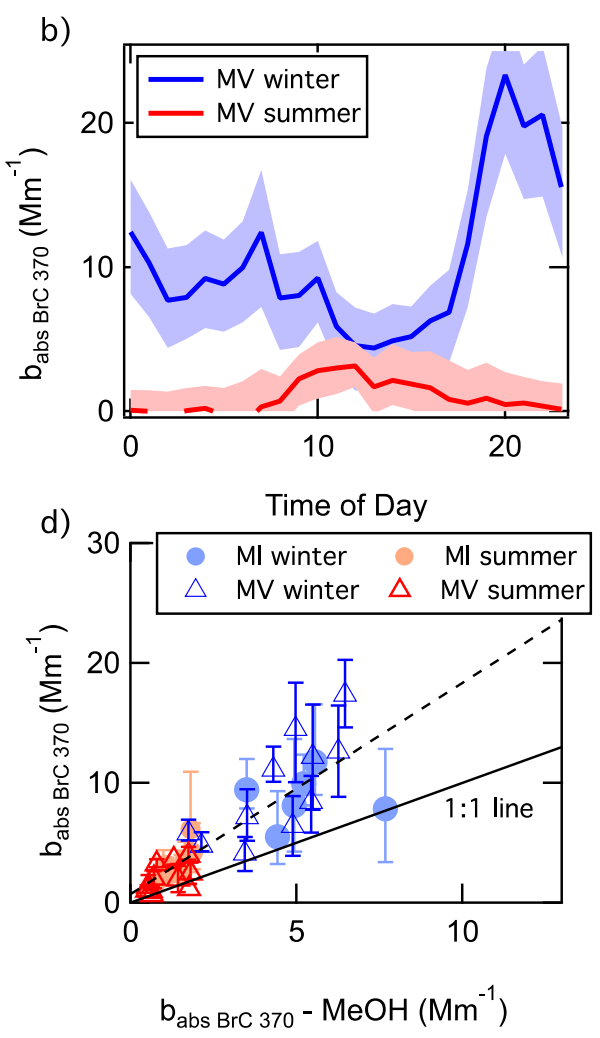

Fig. 4. Diurnal trends of $\mathrm{BrC}$ absorption coefficients at $370 \mathrm{~nm}\left(\mathrm{~b}_{\mathrm{abs} \mathrm{BrC} \mathrm{370}}\right)$ from aethalometer data at the urban site (panel a) and the rural site (panel b), dependence of daily average $b_{a b s ~} \operatorname{BrC} 370$ from aethalometer on levoglucosan concentration, $a$

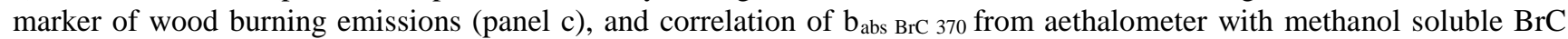
absorption coefficient $\left(\mathrm{b}_{\mathrm{abs} \mathrm{BrC} 370}-\mathrm{MeOH}\right)$ measured off-line with daily resolution (panel $\left.\mathrm{d}\right)$. The shaded areas in panels a and $\mathrm{b}$ and the error bars in panels $\mathrm{c}$ and $\mathrm{d}$ indicate the variability ranges derived from assuming $\mathrm{AAE}_{\mathrm{BC}}$ equal to 0.7 and 1.1 , while the central values are estimated assuming $\mathrm{AAE}_{\mathrm{BC}}$ equal to 0.9. 
and laboratory observations confirm that secondary OA can contribute to aerosol light absorption ( Shapiro et al., 2009; Chang and Thompson, 2010, Hecobian et al., 2010), and therefore can be considered as a form of BrC. Updyke et al. (2012) observed the formation of light-absorbing secondary $\mathrm{OA}$ from the reaction of biogenic and anthropogenic precursors with ammonia in the laboratory, suggesting that the significant emission of ammonia from agricultural activities in the Po Valley can contribute to $\mathrm{BrC}$ summertime loadings in rural areas, which are significantly impacted by agricultural emissions. At the urban site, $b_{a b s} \operatorname{BrC} 370$ diurnal trend is less clear. Previous studies reported high night-time $\mathrm{BrC}$ in urban areas due to dark-chemistry secondary OA or primary OA accumulating near the surface at night (Hecobian et al.,

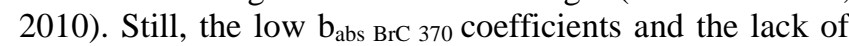
specific organic tracers make difficult to reach a definitive conclusion about the specific sources of $\mathrm{BrC}$ in summer at both urban and rural sites at different times of the day.

To test the attribution of winter $\mathrm{BrC}$ to biomass burning, Fig. 4(c) shows the correlation between the 24-hr wintertime average BrC light absorption at $370 \mathrm{~nm}$ (from Eq. (6)) and $\mathrm{PM}_{1}$ daily concentration of levoglucosan, a wood burning tracer. The data are best fitted by an $\mathrm{AAE}_{\mathrm{BC}}=0.9\left(\mathrm{R}^{2}=0.70\right.$, the solid line), suggesting that $\mathrm{BrC}$ in winter in the Po Valley was strongly related to wood burning from residential heating. The linear fitting functions for the lower and upper bounds of $\mathrm{AAE}_{\mathrm{BC}}$ are indicated by the dashed gray and green lines in Fig. 4(c). The corresponding correlation coefficient

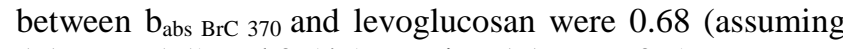
$\left.\mathrm{AAE}_{\mathrm{BC}}=1.1\right)$ and 0.54 (assuming $\left.\mathrm{AAE}_{\mathrm{BC}}=0.7\right)$.

\section{BrC Optical Properties}

To investigate the optical properties of $\mathrm{BrC}, \mathrm{PM}_{1} \mathrm{OA}$ collected daily on quartz filters was extracted with methanol and water, and the UV-VIS light absorption spectra were measured. Table 2 reports the average absorption coefficients of methanol-soluble and water-soluble $\mathrm{BrC}$, and the corresponding $\mathrm{AAE}_{\mathrm{BrC}}$ over the range $330-500 \mathrm{~nm}$. Previous studies show that water extracts less than $70 \%$ of the total light-absorbing OA, while methanol extracts more than $90 \%$ (Chen and Bond 2010; Laskin et al., 2015; Kumar et al., 2018). The absorption coefficients measured in this study confirm that methanol extracts $\mathrm{BrC}$ more efficiently than water, and $\mathrm{AAE}$ values indicate that the two solvents extract $\mathrm{BrC}$ with different optical properties, and likely different chemical composition.

Fig. 4(d) compares methanol soluble $\mathrm{BrC}$ absorption

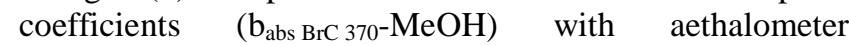
measurements $\left(b_{\text {abs } \mathrm{BrC} 370}\right)$ averaged over 24-hour sampling period at both rural and urban site, in summer and winter. As in previous graphs, the $\mathrm{b}_{\mathrm{abs} \mathrm{BrC} 370}$ from aethalometer data is calculated using Eq. (6) and assuming $\mathrm{AAE}_{\mathrm{BC}}=0.9$. The error bars in Fig. 4(d) are calculated using the upper and lower bound of $\mathrm{b}_{\mathrm{abs} \mathrm{BrC}} 370$ assuming $\mathrm{AAE}_{\mathrm{BC}}$ equal to 0.7 and 1.1 , respectively. Although aethalometer data refer to $\mathrm{PM}_{10}$ aerosol and methanol $\mathrm{BrC}$ measurements were performed on $\mathrm{PM}_{1}$ size fraction, the comparison shows a good correlation between the two parameters for all datasets with an average $\mathrm{R}^{2}=0.74$ and intercept close to zero $(0.7 \pm 0.6)$. However, the orthogonal fit with a slope of 1.8 indicates that a much higher absorption coefficient is measured by the aethalometer. Indeed, particle absorption is expected to be about 1.5-2 times larger than bulk solution absorption for ambient $\mathrm{BrC}$ particles in the accumulation mode, due to size effect (Liu et al., 2013). We can exclude the presence of mineral dust as non-carbonaceous light absorbing material, since iron oxides, responsible for dust light absorption, would not be extracted by methanol and would affect exclusively on-line data, leading to a positive line intercept. The corresponding plot showing the water soluble $\mathrm{BrC}$ absorption is reported in Supplementary material (Fig. S5).

Assuming that the totality of $\mathrm{BrC}$ is extracted by methanol, we calculated the MAC of $\mathrm{BrC}\left(\mathrm{MAC}_{\mathrm{BrC}}\right)$ by dividing the

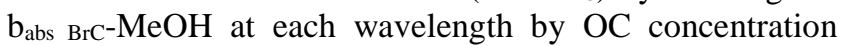
(Fig. 5). Averaged $\mathrm{MAC}_{\mathrm{BrC}}$ at $370 \mathrm{~nm}$ for each site and over each season are reported in Table 2 and vary between 0.3 and $1.2 \mathrm{~m}^{2} \mathrm{~g}^{-1}$.

During summer, $\mathrm{MAC}_{\mathrm{BrC}}$ was in agreement with values reported for urban and rural sites in summer in the United States (Liu et al., 2013, Zhang et al., 2013) and with MAC of secondary OA from anthropogenic and biogenic emissions (Laskin et al., 2015; Liu et al., 2016). The slightly higher $\mathrm{MAC}_{\mathrm{BrC}}$ observed at the urban site in summer might confirm laboratory observations indicating that SOA from anthropogenic aromatic precursors absorbs light more efficiently than SOA from a mixture of anthropogenic and biogenic mixed sources, that might be more characteristic of rural areas (Laskin et al., 2015; Liu et al., 2016).

In winter $\mathrm{MAC}_{\mathrm{BrC}}$ was two to four times higher than summer values $\left(1.2 \mathrm{~m}^{2} \mathrm{~g}^{-1}\right)$. Chen and Bond (2010) measured a $\mathrm{MAC}_{\mathrm{BrC}}$ at $370 \mathrm{~nm}$ for laboratory wood burning experiments between 1.5 and $2 \mathrm{~m}^{2} \mathrm{~g}^{-1}$. BrC from prescribed fires shows a MAC at $365 \mathrm{~nm}$ of $1.3 \mathrm{~m}^{2} \mathrm{~g}^{-1}$ (Xie et al., 2017). Finally, $\mathrm{MAC}_{\mathrm{BrC}}$ of ambient aerosol in areas strongly impacted by residential wood burning emissions ranges between 1.5 and 1.8 (Cheng et al., 2016; Shen et al., 2017). The MAC $\mathrm{BrC}_{\mathrm{Br}}$ reported for this study using the offline measurements is comparable to the lower bound of the literature range of $\mathrm{MAC}_{\mathrm{BrC}}$ from wood burning emissions. This result confirms the impact of biomass combustion as a source of $\mathrm{BrC}$ in the Po valley during the cold season.

To verify the consistency of on-line and off-line measurements, Fig. 6(a) compares the campaign average $\mathrm{AAE}$ of methanol-soluble $\mathrm{BrC}$ with the variability range of the $\mathrm{AAE}_{\mathrm{BrC}}$ from aethalometer data. We calculated the aethalometer $\mathrm{AAE}_{\mathrm{BrC}}$ by subtracting the $\mathrm{BC}$ absorption from the total aerosol absorption at $370 \mathrm{~nm}$ and at $550 \mathrm{~nm}$, and assuming $\mathrm{AAE}_{\mathrm{BC}}$ equal to 0.9 (lower and upper bounds are calculated with $\mathrm{AAE}_{\mathrm{BC}}$ equal to 1.1 and 0.7 , respectively). The aethalometer absorption coefficient at $550 \mathrm{~nm}$ was extrapolated based on the measured aerosol AAE in the range $370-880 \mathrm{~nm}$. The average $\mathrm{AAE}_{\mathrm{BrC}}$ values obtained from off-line and on-line measurements agree well. Over the four experiments $\mathrm{AAE}$ of methanol soluble $\mathrm{BrC}$ ranged between 2.2 and 4.4, in agreement with the lower bound of values reported in literature (from 2 up to 11) (Zhang et al., 2013; Laskin et al., 2015). The AAE variability is due to the complexity of $\mathrm{BrC}$ chemical constituents, which depend on sources and atmospheric processes. 

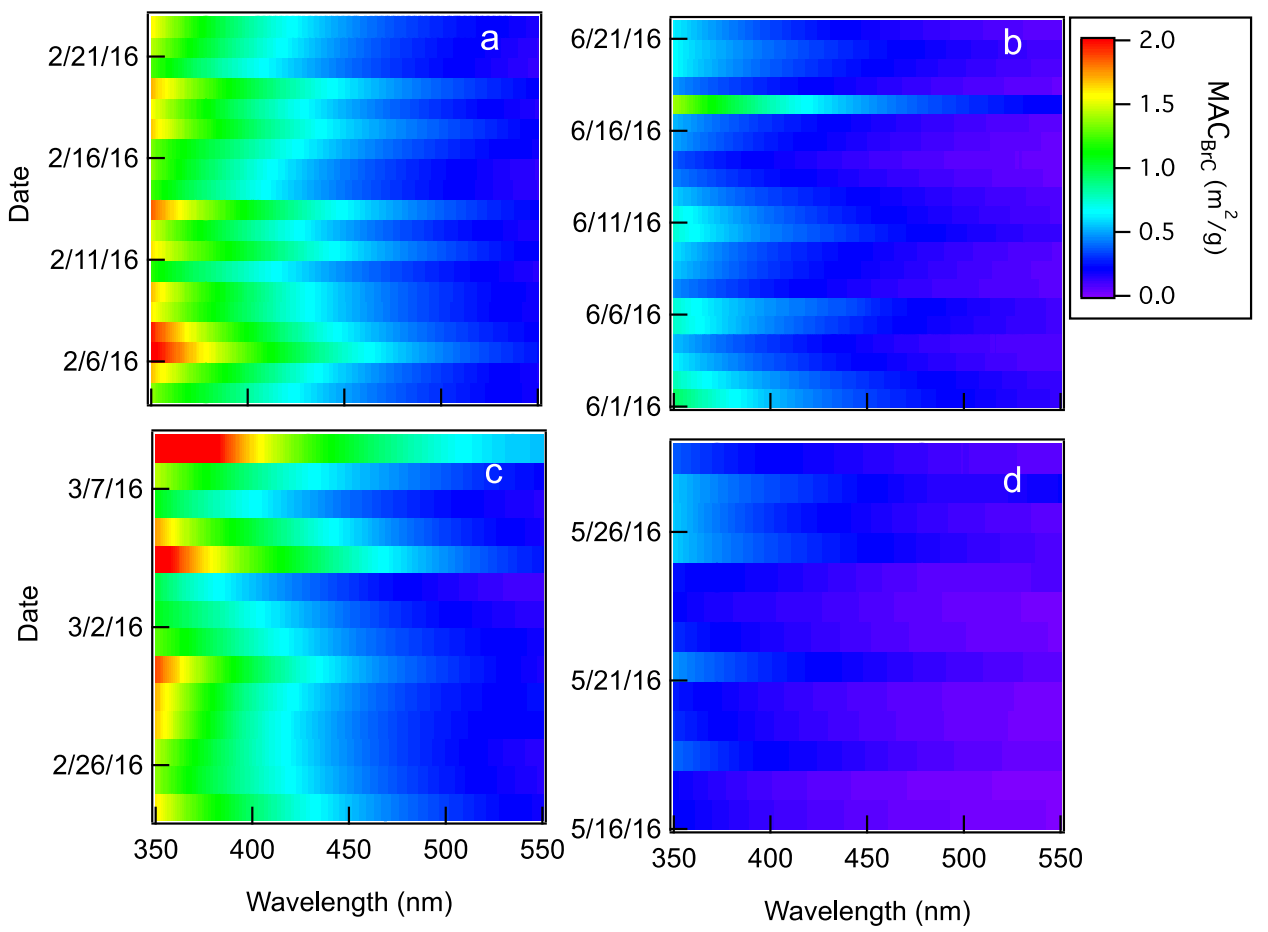

Fig. 5. Brown carbon mass absorption cross section $\left(\mathrm{MAC}_{\mathrm{BrC}}\right)$ versus wavelength and date in Milan in winter (panel a), Milan in summer (panel b), Motta Visconti in winter (panel c), and Motta Visconti in summer (panel d).

Figs. 6(b) and 6(c) investigate the AAE of methanolsoluble $\mathrm{BrC}$ as a function of the $\mathrm{EC}$ to $\mathrm{OC}$ ratio. For ambient measurements, the $\mathrm{EC} / \mathrm{OC}$ ratio is an indicator of primary versus secondary carbonaceous aerosol, and in winter is also related to the different contribution of wood burning and fossil fuel burning to carbonaceous aerosol loading (Sandrini et al., 2014). In winter (Fig. 6(b)) the AAE increased with the decreasing of the EC/OC ratio, reflecting the change between the urban to the rural sites (with rural sites having lower EC/OC ratio). The overall trend is consistent with laboratory experiments showing an increase of the $\mathrm{AAE}_{\mathrm{BrC}}$ associated with aging of wood burning emissions (Saleh $e t$ al., 2014, Xie et al., 2017, Kumar et al., 2018), suggesting that during the cold season the variability of AAE is controlled by wood burning aerosol loading and its atmospheric evolutions. Similarly, in summer (Fig. 6(c)) the highest $\operatorname{AAE}_{\mathrm{BrC}}(\sim 4)$ is observed for the lowest EC/OC ratios (0.1), in agreement with a larger contribution of secondary organic aerosol. At the urban site, AAE displays smaller variability and lower values compared with the rural data. As already suggested by the higher MAC, urban $\mathrm{BrC}$ in summer was likely dominated by anthropogenic SOA from aromatic precursors, whose absorption extends over a larger region of the UV Vis spectra than aliphatic molecules, leading to a lower AAE compared to biogenic SOA (Zhang et al., 2013). The higher $\mathrm{AAE}$ and the lower MAC at the rural location in summer agree with a larger contribution of biogenic SOA.

\section{CONCLUSIONS}

We investigated the seasonal and spatial variability of BC and $\mathrm{BrC}$ absorption across the Po Valley. Ambient measurements of $\mathrm{BC}$ optical properties and a better quantification of $\mathrm{BrC}$ light absorption are necessary to reduce model uncertainty in describing aerosol-radiation interaction, and to improve model ability to predict the short-term and long-term effects of climate policies.

Light absorption measurements performed during this study indicate that $\mathrm{BC}$ concentrations in the urban area are comparable to those observed in other southern European cities; conversely, rural $\mathrm{BC}$ concentrations are higher than expected indicating that $\mathrm{BC}$ impacts in the Po Valley are not limited to urban agglomerates and urban population. Aggressive measures should be implemented to reduce BC emissions from both traffic and wood combustion, as well as agricultural waste burning.

$\mathrm{BC}$ mass absorption cross section was investigated using thermal-optical EC measurements. $\mathrm{MAC}_{\mathrm{EC}}$ showed little seasonl and spatial variability, with an average value of 10.0 $\mathrm{m}^{2} \mathrm{~g}^{-1}$ at $880 \mathrm{~nm}$. Despite the limited dataset investigated, the analysis of $\mathrm{MAC}_{\mathrm{EC}}$ variability suggests that the ratio between non-refractory $\mathrm{PM}_{1}$ and $\mathrm{EC}$ can be used in certain locations as a proxy for $\mathrm{BC}$ coating thickness, to describe BC optical properties variability. Nevertheless, such parameterization relies on assumptions (such as intraparticle mixing configuration) that might limit its general application on short time scales, thus caution is recommended when this kind of approach is applied.

Although characterized by lower absorption efficiency, $\mathrm{BrC}$ contributes together to wavelength absorption. In the Po Valley, $\mathrm{BrC}$ is directly emitted by wood combustion during winter, while it is found in secondary organic aerosol during summer. BrC extraction with methanol and water shows that more than $50 \%$ of light absorbing organic aerosol is water 
a)

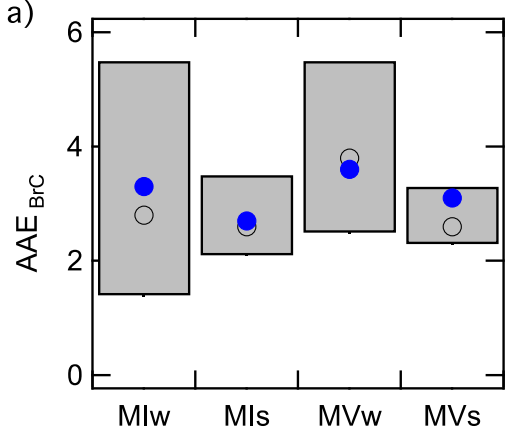

b)

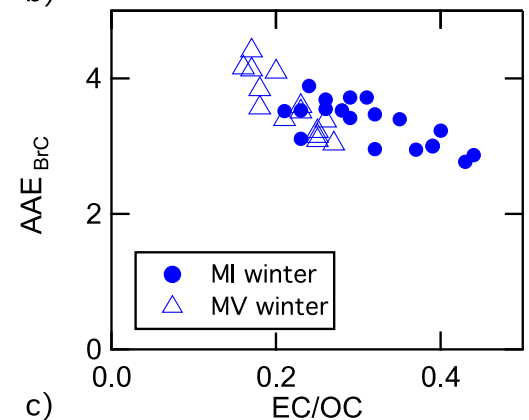

c)

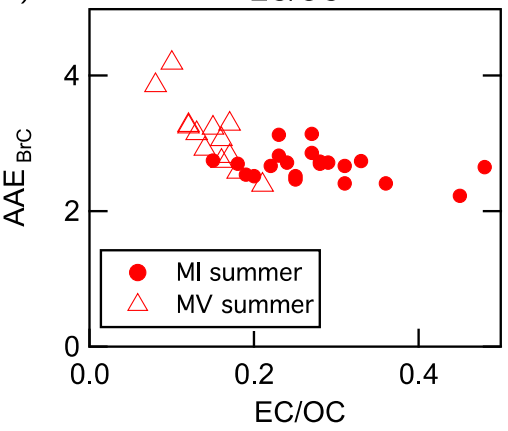

Fig. 6. Panel a: comparison between campaign averages of $\mathrm{AAE}_{\mathrm{BrC}}$ from off-line methanol-soluble $\mathrm{BrC}$ measurements (blue circles) and the $\mathrm{AAE}_{\mathrm{BrC}}$ ranges estimated from on-line aethalometer measurements (gray rectangles); aethalometerbased $\mathrm{AAE}$ ranges are calculated assuming $\mathrm{AAE}_{\mathrm{BC}}$ equal to 0.7 and 1.1, while central value is calculated assuming $\mathrm{AAE}_{\mathrm{BC}}$ equal to 0.9 (open black circles). Panels b and $\mathrm{c}$ : dependence of methanol-soluble BrC Absorption Ångström Exponent $\left(\mathrm{AAE}_{\mathrm{BrC}}\right)$ on the elemental to organic carbon ratio (EC/OC) during the four experiments, in winter and summer, respectively.

insoluble. The water-insoluble fraction is likely dominated by aromatic organic moieties during both seasons, as suggested by the higher $\mathrm{AAE}$ of methanol soluble $\mathrm{BrC}$.

$\mathrm{MAC}_{\mathrm{BrC}}$ differs significantly depending on the sources, with values for secondary organic aerosol (SOA) that are about two times lower than those for biomass combustion. The accurate determination of MAC for specific organic aerosol sources requires coupling source apportionment analysis with optical property measurements, but such analysis is behind the scope of this study.

Ambient observations collected in this study confirm laboratory measurements indicating that the contribution of SOA to light absorption is not negligible. This has significant climate implications. In fact, the radiative impact of $\mathrm{BrC}$, at wavelength larger than $400 \mathrm{~nm}$, is significant over bright surfaces (Chen et al., 2010) such as clouds or snow. The mechanism of formation of $\mathrm{BrC}$ through atmospheric processing of aerosol precursors increases the probability of light absorbing aerosol formation in the upper part of the troposphere, including above clouds, potentially leading to a positive radiative forcing (Zhang et al., 2017). Deposition of $\mathrm{BrC}$ on snow and ice can promote their melting and albedo change (Zhang et al., 2019; Beres et al., 2020). In addition, BrC absorption at short wavelength (below $400 \mathrm{~nm}$ ) reduces atmospheric actinic flux, impacting atmospheric photochemistry and ozone production (Mok et al., 2016). In conclusions, a better knowledge of SOA formation, microphysical, and optical properties is needed to improve the ability of climate models to describe the effect of shortlived climate forcers

\section{ACKNOWLEDGMENTS}

The authors would like to acknowledge Fondazione Cariplo (fund number 2015-1195) for supporting the research activities of the Black Carbon Tool (Black CaT) project.

\section{SUPPLEMENTARY MATERIAL}

Supplementary data associated with this article can be found in the online version at https://doi.org/10.4209/aaqr.2 020.03.0085

\section{REFERENCES}

Andreae, M. and Gelencser, A. (2006). Black carbon or brown carbon? The nature of light-absorbing carbonaceous aerosols. Atmos. Chem. Phys. 6: 3131-3148. https://doi.org/ 10.5194/acp-6-3131-2006

Arnott, W., Hamasha, K., Moosmüller, H., Sheridan, P.J. and Ogren, J.A. (2005). Towards aerosol light-absorption measurements with a 7-wavelength aethalometer: Evaluation with a photoacoustic instrument and 3wavelength nephelometer. Aerosol Sci. Technol. 39: 1729. https://doi.org/10.1080/027868290901972

Barnard, J.C., Volkamer, R. and Kassianov, E.I. (2008). Estimation of the mass absorption cross section of the organic carbon component of aerosols in the Mexico City metropolitan area. Atmos. Chem. Phys. 8: 6665-6679. https://doi.org/10.5194/acp-8-6665-2008

Beres, N., Sengupta, D., Samburova, V., Khlystov, A. and Moosmuller, H. (2020). Deposition of brown carbon onto snow: Changes in snow optical and radiative properties. Atmos. Chem. Phys. 20: 6095-6114. https://doi.org/10.51 94/acp-20-6095-2020

Bhandari, J., China, S., Chandrakar, K.K., Kinney, G., Cantrell, W., Shaw, R.A., Mazzoleni, L.R.,Girotto, G., Sharma, N., Gorkowski, K., Gilardoni, S., Decesari, S., Facchini, M.C., Zanca, N., Pavese, G., Esposito, F., Dubey, M.K., Aiken, A.C., Chakrabarty, R.K., Moosmüller, H., Onasch, T.B., Zaveri, R.A., Scarnato, B. V., Fialho, P. 
and Mazzoleni, C. (2019a). Extensive soot compaction by cloud processing from laboratory and field observations. Sci. Rep. 9: 11824. https://doi.org/10.1038/s41598-01948143-y

Bhandari, J., China, S., Girotto, G., Scarnato, B.V., Gorkowski, K., Aiken, A.C., Dubey, M.K. and Mazzoleni, C. (2019b). Optical properties and radiative forcing of fractal-like tar ball aggregates from biomass burning. $J$. Quant. Spectrosc. Radiat. Transfer 230: 65-74. https://doi.org/10.1016/j.jqsrt.2019.01.032

Blanco-Alegre, C., Calvo, A., Alves, C., Fialho, P., Nunes, T., Gomes, J., Castro, A., Oduber, F., Coz, E. and Fraile, R. (2020). Aethalometer measurements in a road tunnel: A step forward in the characterization of black carbon emissions from traffic. Sci. Total Environ. 703: 135483. https://doi.org/10.1016/j.scitotenv.2019.135483

Bond, T.C. and Bergstrom, R.W. (2006). Light absorption by carbonaceous particles: An investigative review. Aerosol Sci. Technol. 40: 27-67. https://doi.org/10.1080/ 02786820500421521

Bond, T., Doherty, S., Fahey, D., Forster, P., Berntsen, T., DeAngelo, B., Flanner, M., Ghan, S., Karcher, B., Koch, D., Kinne, S., Kondo, Y., Quinn, P., Sarofim, M., Schultz, M., Schulz, M., Venkataraman, C., Zhang, H., Zhang, S., Bellouin, N., Guttikunda, S., Hopke, P., Jacobson, M., Kaiser, J., Klimont, Z., Lohmann, U., Schwarz, J., Shindell, D., Storelvmo, T., Warren S. and Zender C. (2013). Bounding the role of black carbon in the climate system: A scientific assessment. J. Geophys. Res. 118: 5380 5552. https://doi.org/10.1002/jgrd.50171

Brown, H., Liu, X., Feng, Y., Jiang, Y., Wu, M., Lu, Z., Wu, C., Murphy, S. and Pokhrel, R. (2018). Radiative effect and climate impacts of brown carbon with the Community Atmosphere Model (CAM5). Atmos. Chem. Phys. 18: 17745-17768. https://doi.org/10.5194/acp-18-17745-2018

Browne, E.C., Zhang, X., Franklin, J.P., Ridley, K.J., Kirchstetter, T.W., Wilson, K.R., Cappa, C.D. and Kroll, J.H. (2019). Effect of heterogeneous oxidative aging on light absorption by biomass burning organic aerosol. Aerosol Sci. Technol. 53: 663-674. https://doi.org/10.108 0/02786826.2019.1599321

Buseck, P.R., Adachi, K., Gelencsér, A., Tompa, É. and Pósfai, M. (2014). Ns-soot: A material based term for strongly light-absorbing carbonaceous particles. Aerosol Sci. Technol. 48: 777-788. https://doi.org/10.1080/02786 826.2014.919374

Cappa, C., Onasch, T., Massoli, P., Worsnop, D., Bates, T., Cross, E., Davidovits, P., Hakala, J., Hayden, K., Jobson, B., Kolesar, K., Lack, D., Lerner, B., Li, S., Mellon, D., Nuaaman, I., Olfert, J., Petaja, T., Quinn, P., Song, C., Subramanian, R., Williams E. and Zaveri R. (2012). Radiative absorption enhancements due to the mixing state of atmospheric black carbon. Science 337: 10781081. https://doi.org/10.1126/science. 1223447

Chakrabarty, R.K. and Heinson, W.R. (2018). Scaling laws for light absorption enhancement due to nonrefractory coating of atmospheric black carbon aerosol. Phys. Rev. Lett. 121: 218701. https://doi.org/10.1103/PhysRevLett.1 21.218701
Chakrabarty, R.K., Moosmüller, H., Arnott, W.P., Garro, M.A. and Walker, J. (2006). Structural and fractal properties of particles emitted from spark ignition engines. Environ. Sci. Technol. 40: 6647-6654. https://doi.org/10.1021/es0 $60537 y$

Chakrabarty, R.K., Moosmüller, H., Chen, L.W.A., Lewis, K., Arnott, W.P., Mazzoleni, C., Dubey, M.K., Wold, C.E., Hao, W.M. and Kreidenweis, S.M. (2010). Brown carbon in ar balls from smoldering biomass combustion. Atmos. Chem. Phys. 10: 6363-6370. https://doi.org/10.51 94/acp-10-6363-2010

Chang, J.L. and Thompson, J.E. (2010). Characterization of colored products formed during irradiation of aqueous solutions containing $\mathrm{H}_{2} \mathrm{O}_{2}$ and phenolic compounds. Atmos. Environ. 44: 541-551. https://doi.org/10.1016/j.a tmosenv.2009.10.042

Chen, Y. and Bond, T.C. (2010). Light absorption by organic carbon from wood combustion. Atmos. Chem. Phys. 10: 1773-1787. https://doi.org/10.5194/acp-10-1773-2010

Cheng, Y., He, K.B., Du, Z.Y., Engling, G., Liu, J.M., Ma, Y.L., Zheng M. and Weber, R.J. (2016). The characteristics of brown carbon aerosol during winter in Beijing. Atmos. Environ. 127: 355-364. https://doi.org/10.1016/j.atmose nv.2015.12.035

China, S., Mazzoleni, C., Gorkowski, K., Aiken, A.C. and Dubey, M.K. (2013). Morphology and mixing state of individual freshly emitted wild fire carbonaceous particles. Nat. Commun. 4: 2122. https://doi.org/10.1038/ ncomms3122

China, S., Scarnato, B., Owen, R.C., Zhang, B., Ampadu, M. T., Kumar, S., Dzepina, K., Dziobak, M.P., Fialho, P., Perlinger, J.A., Hueber, J., Helmig, D., Mazzoleni, L.R., and Mazzoleni, C. (2015). Morphology and mixing state of aged soot particles at a remote marine free troposphere site: Implications for optical properties. Geophys. Res. Lett. 42: 1243-1250. https://doi.org/10.1002/2014GL06 2404

Chung, C.E., Kim, S.W., Lee, M., Yoon, S.C. and Lee, S. (2012a). Carbonaceous aerosol AAE inferred from in-situ aerosol measurements at the Gosan ABC super site, and the implications for brown carbon aerosol. Atmos. Chem. Phys. 12: 6173-6184. https://doi.org/10.5194/acp-126173-2012

Chung, C.E., Ramanathan, V. and Decremer, D. (2012b). Observationally constrained estimates of carbonaceous aerosol radiative forcing. Proc. Natl. Acad. Sci. U.S.A. 109: 11624-11629. https://doi.org/10.1073/pnas. 120370 7109

Collaud Coen, M., Weingartner, E., Apituley, A., Ceburnis, D., Fierz-Schmidhauser, R., Flentje, H., Henzing, J.S., Jennings, S.G., Moerman, M., Petzold, A., Schmid O. and Baltensperger, U. (2010). Minimizing light absorption measurement artifacts of the Aethalometer: Evaluation of five correction algorithms. Atmos. Meas. Tech. 3: 457474. https://doi.org/10.5194/amt-3-457-2010

Costabile, F., Gilardoni, S., Barnaba, F., Di Ianni, A., Di Liberto, L., Dionisi, D., Manigrasso, M., Paglione, M., Poluzzi, V., Rinaldi, M., Facchini M.C. and Gobbi, G.P. (2017). Characteristics of brown carbon in the urban Po 
Valley atmosphere. Atmos. Chem. Phys. 17: 313-326. https://doi.org/10.5194/acp-17-313-2017

Cross, E.S., Onasch, T.B., Ahern, A., Wrobel, W., Slowik, J.G., Olfert, J., Lack, D.A., Massoli, P., Cappa, C.D., Schwarz, J.P., Spackman, J.R., Fahey, D.W., Sedlacek, A., Trimborn, A., Jayne, J.T., Freedman, A., Williams, L.R., Ng, N.L., Mazzoleni, C., Dubey, M., Brem, B., Kok, G., Subramanian, R., Freitag, S., Clarke, A., Thornhill, D., Marr, L.C., Kolb, C.E., Worsnop, D.R. and Davidovits, P. (2010). Soot particle studies-instrument intercomparison-project overview. Aerosol Sci. Technol. 44: 592-611. https://doi.org/10.1080/02786826.2010.482113

Ealo, M., Alastuey, A., Pérez, N., Ripoll, A., Querol, X. and Pandolfi, M. (2018). Impact of aerosol particle sources on optical properties in urban, regional and remote areas in the north-western Mediterranean. Atmos. Chem. Phys. 18: 1149-1169. https://doi.org/10.5194/acp-18-1149-2018

Feng, Y., Ramanathan, V. and Kotamarthi, V.R. (2013). Brown carbon: A significant atmospheric absorber of solar radiation? Atmos. Chem. Phys. 13: 8607-8621. https://doi.org/10.5194/acp-13-8607-2013

Fierce, L., Onasch, T.B., Cappa, C.D., Mazzoleni, C., China, S., Bhandari, J., Davidovits, P., Fischer, D.A., Helgestad, T., Lambe, A.T., Sedlacek, A.J., Smith, G.D. and Wol, L. (2020). Radiative absorption enhancements by black carbon controlled by particle-to-particle heterogeneity in composition. Proc. Natl. Acad. Sci. U.S.A. 117: 51965203. https://doi.org/10.1073/pnas.1919723117

Forestieri, S.D., Helgestad, T.M., Lambe, A.T., RenbaumWol, L., Lack, D.A., Massoli, P., Cross, E.S., Dubey, M.K., Mazzoleni, C., Olfert, J.S., Sedlacek III, A.J., Freedman, A., Davidovits, P., Onasch, T.B. and Cappa, C.D. (2018). Measurement and modeling of the multiwavelength optical properties of uncoated flamegenerated soot. Atmos. Chem. Phys. 18: 12141-12159. https://doi.org/10.5194/acp-18-12141-2018

Forrister, H., Liu, J., Scheuer, E., Dibb, J., Ziemba, L., Thornhill, K.L., Anderson, B., Diskin, G., Perring, A. E., Schwarz, J.P., Campuzano-Jost, P., Day, D.A., Palm, B. B., Jimenez, J.L., Nenes, A. and Weber, R.J. (2015). Evolution of brown carbon in wild fire plumes. Geophys. Res. Lett. 42: 4623-4630. https://doi.org/10.1002/2015G L063897

Genberg, J., Denier van der Gon, H.A.C., Simpson, D., Swietlicki, E., Areskoug, H., Beddows, D., Ceburnis, D., Fiebig, M., Hansson, H.C., Harrison, R.M., Jennings, S.G., Saarikoski, S., Spindler, G., Visschedijk, A.J.H., Wiedensohler, A. and Yttri, K. (2013). Light-absorbing carbon in Europe - measurement and modelling, with a focus on residential wood combustion emissions. Atmos. Chem. Phys. 13:8719-8738. https://doi.org/10.5194/acp13-8719-2013

Gilardoni, S., Vignati, E., Marmer, E., Cavalli, F., Belis, C., Gianelle, V., Loureiro, A. and Artaxo, P. (2011). Sources of carbonaceous aerosol in the Amazon basin. Atmos. Chem. Phys. 11: 2747-2764. https://doi.org/10.5194/acp11-2747-2011

Gilardoni, S., Massoli, P., Giulianelli, L., Rinaldi, M., Paglione, M., Pollini, F., Lanconelli, C., Poluzzi, V.,
Carbone, S., Hillamo, R., Russell, L.M., Facchini, M.C. and Fuzzi, S. (2014). Fog scavenging of organic and inorganic aerosol in the Po Valley. Atmos. Chem. Phys. 14: 6967-6981. https://doi.org/10.5194/acp-14-6967-2014

Gilardoni, S., Massoli, P., Paglione, M., Giulianelli, L., Carbone, C., Rinaldi, M., Decesari, S., Sandrini, S., Costabile, F., Gobbi, G.P., Pietrogrande, M.C., Visentin, M., Scotto, F., Fuzzi, S. and Facchini, M.C. (2016). Direct observation of aqueous secondary organic aerosol from biomass-burning emissions. Proc. Natl. Acad. Sci. U.S.A. 113: 10013-10018. https://doi.org/10.1073/pnas.160221 2113

Gustafsson, Ö. and Ramanathan, V. (2016). Convergence on climate warming by black carbon aerosols. Proc. Natl. Acad. Sci. U.S.A. 113: 4243-4245. https://doi.org/10.107 3/pnas.1603570113

Habib, G., Venkataraman, C., Bond, T.C. and Schauer, J.J. (2008). Chemical, microphysical and optical properties of primary particles from the combustion of biomass fuels. Environ. Sci. Technol. 42: 8829-8834. https://doi.org/10. 1021/es800943f

Hecobian, A., Zhang, X., Zheng, M., Frank, N., Edgerton, E.S. and Weber, R.J. (2010). Water-soluble organic aerosol material and the light-absorption characteristics of aqueous extracts measured over the southeastern United States. Atmos. Chem. Phys. 10: 5965-5977. https://doi.org/10.51 94/acp-10-5965-2010

Inemar (2014). http://www.inemar.eu/xwiki/bin/view/Ine mar/WebHome

IPCC (2013). Summary for Policymakers. In Climate Change 2013: The physical science basis. Contribution of Working Group I to the Fifth Assessment Report of the Intergovernmental Panel on Climate Change, Stocker, T.F., Qin, D., Plattner, G.K., Tignor, M., Allen, S.K., Boschung, J., Nauels, A., Xia, Y., Bex, V. and Midgley, P.M. (Eds.), Cambridge University Press, Cambridge, United Kingdom and New York, NY, USA.

IPCC (2018). Summary for Policymakers. In Global Warming of $1.5^{\circ} \mathrm{C}$. An IPCC Special Report on the impacts of global warming of $1.5^{\circ} \mathrm{C}$ above pre-industrial levels and related global greenhouse gas emission pathways, in the context of strengthening the global response to the threat of climate change, sustainable development, and efforts to eradicate poverty, MassonDelmotte, V., Zhai, P., Pörtner, H.O., Roberts, D., Skea, J., Shukla, P.R., Pirani, A., Moufouma-Okia, W., Péan, C., Pidcock, R., Connors, S., Matthews, J.B.R., Chen, Y., Zhou, X., Gomis, M.I., Lonnoy, E., Maycock, T., Tignor, M. and Waterfield, T. (Eds.), World Meteorological Organization, Geneva, Switzerland.

Jia, G., Shevliakova, E., Artaxo, P., De Noblet-Ducoudré, N., Houghton, R., House, J., Kitajima, K., Lennard, C., Popp, A., Sirin, A., Sukumar, R. and Verchot, L. (2019). Land-climate interactions. In Climate Change and Land: An IPCC special report on climate change, desertification, land degradation, sustainable land management, food security, and greenhouse gas fluxes in terrestrial ecosystems, Shukla, P.R., Skea, J., Calvo Buendia, E., Masson-Delmotte, V., Pörtner, H.O., Roberts, D.C., Zhai, 
P., Slade, R., Connors, S., van Diemen, R., Ferrat, M., Haughey, E., Luz, S., Neogi, S., Pathak, M., Petzold, J., Portugal Pereira, J., Vyas, P., Huntley, E., Kissick, K., Belkacemi, M. and Malley, J. (Eds.), Intergovernmental Panel on Climate Change.

Jo, D.S., Park, R.J., Lee, S., Kim, S.W. and Zhang, X. (2016). A global simulation of brown carbon: Implications for photochemistry and direct radiative effect. Atmos. Chem. Phys. 16: 3413-3432. https://doi.org/10.5194/acp16-3413-2016

John, W. (2005). Size distribution characteristics of aerosols, in aerosol measurement, 2nd ed., Baron, P.A. and Willeke, K. (Eds.), Wiley and Sons, Hoboken, pp. 99 115.

Karanasiou, A., Minguillón, M. C., Viana, M., Alastuey, A., Putaud, J.P., Maenhaut, W., Panteliadis, P., Močnik, G., Favez, O. and Kuhlbusch, T.A.J. (2015). Thermal-optical analysis for the measurement of elemental carbon (EC) and organic carbon (OC) in ambient air a literature review. Atmos. Meas. Tech. Discuss. 8: 9649-9712. https://doi.org/10.5194/amtd-8-9649-2015

Kirchstetter, T., Novakov, T. and Hobbs, P. (2004). Evidence that the spectral dependence of light absorption by aerosols is affected by organic carbon. J. Geophys. Res. 109: D21208. https://doi.org/10.1029/2004jd004999

Kirchstetter, T. and Thatcher, T.L. (2012). Contribution of organic carbon to wood smoke particulate matter absorption of solar radiation. Atmos. Chem. Phys. 12: 6067-6072. https://doi.org/10.5194/acp-12-6067-2012

Kumar, N.K., Corbin, J.C., Bruns, E.A., Massabò, D., Slowik, J.G., Drinovec, L., Močnik, G., Prati, P., Vlachou, A., Baltensperger, U., Gysel, N., El-Haddad, I.P. and Prévôt, A.H.S. (2018). Production of particulate brown carbon during atmospheric aging of wood-burning emissions. Atmos. Chem. Phys. 18: 17843-17861. https://doi.org/10. 5194/acp-18-17843-2018

Lack, D. and Cappa, C. (2010). Impact of brown and clear carbon on light absorption enhancement, single scatter albedo and absorption wavelength dependence of black carbon. Atmos. Chem. Phys. 10: 4207-4220. https://doi.org/10.5194/acp-10-4207-2010

Lack, D.A., Cappa, C.D., Covert, D.S., Baynard, T., Massoli, P., Sierau, B., Bates, T.S., Quinn, P.K., Lovejoy, E.R. and Ravishankara, A. (2008). Bias in filter-based aerosol light absorption measurements due to organic aerosol loading: Evidence from ambient measurements. Aerosol Sci. Technol. 42: 1033-1041. https://doi.org/10.1080/027868 20802389277

Lack, D.A., Cappa, C.D., Cross, E.S., Massoli, P., Ahern, A.T., Davidovits, P. and Onasch, T.B. (2009). Absorption enhancement of coated absorbing aerosols: Validation of the photo-acoustic technique for measuring the enhancement. Aerosol Sci. Technol. 43: 1006-1012. https://doi.org/10.1 080/02786820903117932

Larsen, B.R., Gilardoni, S., Stenstrom, K., Niedzialek, J., Jimenez, J. and Belis, C.A. (2012). Sources for PM air pollution in the Po Plain, Italy: II. Probabilistic uncertainty characterization and sensitivity analysis of secondary and primary sources. Atmos. Environ. 50: 203-213. https://doi.org/10.1016/j.atmosenv.2011.12.038

Laskin, A., Laskin, J. and Nizkorodov, S.A. (2015). Chemistry of atmospheric brown carbon. Chem. Rev. 115: 4335-4382. https://doi.org/10.1021/cr5006167

Lewis, K., Arnott William, P., Moosmüller, H. and Wold, C.E. (2008). Strong spectral variation of biomass smoke light absorption and single scattering albedo observed with a novel dual-wavelength photoacoustic instrument. J. Geophys. Res. 113: D16203. https://doi.org/10.1029/2 007JD009699

Li, J., Liu, C., Yin, Y. and Kumar, K. (2016). Numerical investigation on the angstrom ngstrom exponent of black carbon aerosol. J. Geophys. Res. 121: 3506-3518. https://doi.org/10.1002/2015jd024718

Liu, F., Yon, J., Fuentes, A., Lobo, P., Smallwood, G.J. and Corbin, J.C. (2020). Review of recent literature on the light absorption properties of black carbon: Refractive index, mass absorption cross section, and absorption function. Aerosol Sci. Technol. 54: 33-51. https://doi.org/10.1080/ 02786826.2019.1676878

Liu, J., Bergin, M., Guo, H., King, L., Kotra, N., Edgerton, E. and Weber, R.J. (2013). Size-resolved measurements of brown carbon in water and methanol extracts and estimates of their contribution to ambient fine-particle light absorption. Atmos. Chem. Phys. 13: 12389-12404. https://doi.org/10.5194/acp-13-12389-2013

Liu, J., Lin, P., Laskin, A., Laskin, J., Kathmann, S.M., Wise, M., Caylor, R., Imholt, F., Selimovic, V. and Shilling, J.E. (2016). Optical properties and aging of light-absorbing secondary organic aerosol. Atmos. Chem. Phys. 16: 12815-12827. https://doi.org/10.5194/acp-1612815-2016

Liu, S., Aiken, A.C., Gorkowski, K., Dubey, M.K., Cappa, C.D., Williams, L.R., Herndon, S.C., Massoli, P., Fortner, E.C., Chhabra, P.S., Brooks, W. A., Onasch, T. B., Jayne, J.T., Worsnop, D.R., China, S., Sharma, N., Mazzoleni, C., Xu, L., Ng, N.L., Liu, D., Allan, J.D., Lee, J.D., Fleming, Z., Mohr, C., Zotter, P., Szidat, S. and Prévôt, A.H. (2015). Enhanced light absorption by mixed source black and brown carbon particles in UK winter. Nat. Commun. 6: 8435. https://doi.org/10.1038/ncomms9435

Lonati, G., Crippa, M., Gianelle, V. and Van Dingenen, R. (2011). Daily patterns of the multi-modal structure of the particle number size distribution in milan, italy. Atmos. Environ. 45: 2434-2442. https://doi.org/10.1016/j.atmos env.2011.02.003

Martinsson, J., Azeem, H.A., Sporre, M.K., Bergstrom, R., Ahlberg, E., Ãstrom, E., Kristensson, A., Swietlicki, E. and Stenstrom, K.E. (2017). Carbonaceous aerosol source apportionment using the Aethalometer model AAE evaluation by radiocarbon and levoglucosan analysis at a rural background site in southern Sweden. Atmos. Chem. Phys. 17: 4265-4281. https://doi.org/10.5194/acp-174265-2017

Moffet, R.C. and Prather, K.A. (2009). In-situ measurements of the mixing state and optical properties of soot with implications for radiative forcing estimates. Proc. Natl. Acad. Sci. U.S.A. 106: 11872-11877. https://doi.org/10.1 073/pnas.0900040106 
Moise, T., Flores, J.M. and Rudich, Y. (2015). Optical properties of secondary organic aerosols and their changes by chemical processes. Chem. Rev. 115: 44004439. https://doi.org/10.1021/cr5005259

Mok, J., Krotkov, N., Arola, A., Torres, O., Jethva, H., Andrade, M., Labow, G., Eck, T., Li, Z., Dickerson, R.R., Stenchikov, G.L., Osipov, S. and Ren, X. (2016). Impacts of brown carbon from biomass burning on surface UV and ozone photochemistry in the Amazon Basin. Sci. Rep. 6: 36940. https://doi.org/10.1038/srep36940

Moosmüller, H., Chakrabarty, R.K. and Arnott, W.P. (2009). Aerosol light absorption and its measurement: A review. J. Quant. Spectros. Radiat. Transf. 110: 844-878. https://doi.org/10.1016/j.jqsrt.2009.02.035

Müller, T., Laborde, M., Kassell, G.W. and Wiedensoler, A. (2011). Design and performance of a three-wavelength LED-based total scatter and backscatter integrating nephelometer. Atmos. Meas. Tech. 4: 1291-1303. https://doi.org/10.5194/amt-4-1291-2011

Müller, T., Nowak, A., Wiedensohler, A., Sheridan, P., Laborde, M., Covert, D.S., Marinoni, A., Imre, K., Henzing, B., Roger, J.C., Martins dos Santos, S., Wilhelm, R., Wang, Y.Q. and de Leeuw, G. (2009). Angular illumination and truncation of three different integrating nephelometers: Implications for empirical, size-based corrections. Aerosol Sci. Technol. 43: 581-586. https://doi.org/10.1080/02786 820902798484

Nakayama, T., Kondo, Y., Moteki, N., Sahu, L., Kinase, T., Kita, K. and Matsumi, Y. (2010). Size-dependent correction factors for absorption measurements using filter-based photometers: PSAP and COSMOS. $J$. Aerosol Sci. 41: 333-343. https://doi.org/10.1016/j.jaero sci.2010.01.004

Onasch, T.B., Massoli, P., Kebabian, P.L., Hills, F.B., Bacon, F.W. and Freedman, A. (2015). Single scattering albedo monitor for airborne particulates. Aerosol Sci. Technol. 49: 267-279. https://doi.org/10.1080/02786826.2015.10 22248

Park, R.J., Kim, M.J., Jeong, J.I., Youn, D. and Kim, S. (2010). A contribution of brown carbon aerosol to the aerosol light absorption and its radiative forcing in east Asia. Atmos. Environ. 44: 1414-1421. https://doi.org/10. 1016/j.atmosenv.2010.01.042

Peng, J., Hu, M., Guo, S., Du, Z., Zheng, J., Shang, D., Levy Zamora, M., Zeng, L., Shao, M., Wu, Y.S., Zheng, J., Wang, Y., Glen, C.R., Collins, D.R., Molina, M.J. and Zhang, R. (2016). Markedly enhanced absorption and direct radiative forcing of black carbon under polluted urban environments. Proc. Natl. Acad. Sci. U.S.A. 113: 4266-4271. https://doi.org/10.1073/pnas.1602310113

Peterson, M.R. and Richards, M.H. (2002). Thermaloptical-transmittance analysis for organic, elemental, carbonate, total carbon, and OCX2 in PM2. 5 by the EPA/NIOSH method. In Proceedings, Symposium on Air Quality Measurement Methods and Technology-2002. Air \& Waste Management Association, Pittsburgh, PA.

Petzold, A., Kopp, C. and Niessner, R. (1997). The dependence of the specific attenuation cross-section on black carbon mass fraction and particle size. Atmos. Environ. 31: 661-
672. https://doi.org/10.1016/S1352-2310(96)00245-2

Reche, C., Querol, X., Alastuey, A., Viana, M., Pey, J., Moreno, T., Rodriguez, S., Gonzalez, Y., FernandezCamacho, R., Sanchez de la Campa, A.M., de la Rosa, J. Dall'Osto, M., Prevot, A.S.H., Hueglin, A.C., Harrison, R.M. and Quincey, P. (2011). New considerations for PM, Black Carbon and particle number concentration for air quality monitoring across different European cities. Atmos. Chem. Phys. 11: 6207-6227. https://doi.org/10.51 94/acp-11-6207-2011

Saarikoski, S., Carbone, S., Decesari, S., Giulianelli, L., Angelini, F., Canagaratna, M., Ng, N.L., Trimborn, A., Facchini, M.C., Fuzzi, S., Hillamo, R. and Worsnop, D. (2012). Chemical characterization of springtime submicrometer aerosol in Po Valley, Italy. Atmos. Chem. Phys. 12: 8401-8421. https://doi.org/10.5194/acp-128401-2012

Saleh, R., Robinson, E.S., Tkacik, D.S., Ahern, A.T., Liu, S., Aiken, A.C., Sullivan, R.C., Presto, A.A., Dubey, M.K., Yokelson, R.J., Donahue, N.M. and Robinson, A.L. (2014). Brownness of organics in aerosols from biomass burning linked to their black carbon content. Nat. Geosci. 7: 647-650. https://doi.org/10.1038/ngeo2220

Saliba, G., Subramanian, R., Saleh, R., Ahern, A. T., Lipsky, E.M., Tasoglou, A., Sullivan, R.C., Bhandari, J., Mazzoleni, C. and Robinson, A.L. (2016). Optical properties of black carbon in cookstove emissions coated with secondary organic aerosols: Measurements and modeling. Aerosol Sci. Technol. 50: 1264-1276. https://doi.org/10.1080/027 86826.2016.1225947

Sandrini, S., Fuzzi, S., Piazzalunga, A., Prati, P., Bonasoni, P., Cavalli, F., Bove, M.C., Calvello, M., Cappelletti, D., Colombi, C., Contini, D., de Gennaro, G., Di Gilio, A., Fermo, P., Ferrero, L., Gianelle, V., Giugliano, M., Ielpo, P., Lonati, G., Marinoni, A., Massabo, D., Molteni, U. Moroni, B., Pavese, G., Perrino, C., Perrone, M.G., Perrone, M.R., Putaud, J.P., Sargolini, T., Vecchi, R. and Gilardoni, S. (2014). Spatial and seasonal variability of carbonaceous aerosol across Italy. Atmos. Environ. 99: 587-598. https://doi.org/10.1016/j.atmosenv.2014.10.032

Saturno, J., Holanda, B.A., Pöhlker, C., Ditas, F., Wang, Q., Moran-Zuloaga, D., Brito, J., Carbone, S., Cheng, Y., Chi, X., Ditas, J., Hoffmann, T., Hrabe de Angelis, I., Könemann, T., Lavrič, J.V., Ma, N., Ming, J., Paulsen, H., Pöhlker, M.L., Rizzo, L.V., Schlag, P., Su, H., Walter, D., Wolff, S., Zhang, Y., Artaxo, P., Pöschl, U. and Andreae, M.O. (2018). Black and brown carbon over central Amazonia: Long-term aerosol measurements at the ATTO site. Atmos. Chem. Phys. 18: 12817-12843. https://doi.org/10.5194/acp-18-12817-2018

Sciare, J., d'Argouges, O., Sarda-Esteve, R., Gaimoz, C., Dolgorouky, C., Bonnaire, N., Favez, O., Bonsang, B. and Gros, V. (2011). Large contribution of water-insoluble secondary organic aerosols in the region of Paris (France) during wintertime. J. Geophys. Res. 116: D22203. https://doi.org/10.1029/2011JD015756

Sedlacek III, A.J., Buseck, P.R., Adachi, K., Onasch, T.B., Springston, S.R. and Kleinman, L. (2018). Formation and evolution of tar balls from northwestern us wild res. 
Atmos. Chem. Phys. 18: 11289-11301. https://doi.org/10. 5194/acp-18-11289-2018

Shapiro, E.L., Szprengiel, J., Sareen, N., Jen, C.N., Giordano, M. and Mcneill, V.F. (2009). Light-absorbing secondary organic material formed by glyoxal in aqueous aerosol mimics. Atmos. Chem. Phys. 9: 2289-2300. https://doi.org/10.5194/acp-9-2289-2009

Sharma, N., Arnold, I.J., Moosmüller, H., Arnott, W.P. and Mazzoleni, C. (2013). Photoacoustic and nephelometric spectroscopy of aerosol optical properties with a supercontinuum light source. Atmos. Meas. Tech. 6: 3501-3513. https://doi.org/10.5194/amt-6-3501-2013

Shen, Z., Zhang, Q., Cao, J., Zhang, L., Lei, Y., Huang, Y., Huang, R.J., Gao, J., Zhao, Z., Zhu, C., Yin, X., Zheng, C., Xu, H. and Liu, S. (2017). Optical properties and possible sources of brown carbon in $\mathrm{PM}_{2.5}$ over Xi'an, China. Atmos. Environ. 150: 322-330. https://doi.org/10. 1016/j.atmosenv.2016.11.024

Shiraiwa, M., Kondo, Y., Iwamoto, T. and Kita, K. (2010). Amplification of light absorption of black carbon by organic coating. Aerosol Sci. Technol. 44: 46-54. https://doi.org/10.1080/02786820903357686

Subramanian, R., Roden, C.A., Boparai, P. and Bond, T.C. (2007). Yellow beads and missing particles: Trouble ahead for filter-based absorption measurements. Aerosol Sci. Technol. 41: 630-637. https://doi.org/10.1080/02786 820701344589

Sumlin, B.J., Pandey, A., Walker, M.J., Pattison, R.S., Williams, B.J. and Chakrabarty, R.K. (2017). Atmospheric photooxidation diminishes light absorption by primary brown carbon aerosol from biomass burning. Environ. Sci. Technol. Lett. 4: 540-545. https://doi.org/10.1021/ac s.estlett.7b00393

Tsigaridis, K. and Kanakidou, M. (2018). The present and future of secondary organic aerosol direct forcing on climate. Curr. Clim. Change Rep. 4: 84-98. https://doi.org/ 10.1007/s40641-018-0092-3

Updyke, K.M., Nguyen, T.B. and Nizkorodov, S.A. (2012). Formation of brown carbon via reactions of ammonia with secondary organic aerosols from biogenic and anthropogenic precursors. Atmos. Environ. 63: 22-31. https://doi.org/10.1016/j.atmosenv.2012.09.012

Xie, M., Hays, M.D. and Holder, A.L. (2017). Lightabsorbing organic carbon from prescribed and laboratory biomass burning and gasoline vehicle emissions. Sci. Rep. 7: 7318. https://doi.org/10.1038/s41598-017-06981-8

Yuan, J.F., Huang, X.F., Cao, L.M., Cui, J., Zhu, Q., Huang, C.N. and Lan, Z.J. and He, L.Y. (2016). Light absorption of brown carbon aerosol in the PRD region of China. Atmos. Chem. Phys. 18: 1433-1443. https://doi.org/10.51 94/acp-16-1433-2016

Zanatta, M., Gysel, M., Bukowiecki, N., Müller, T., Weingartner, E., Areskoug, H., Fiebig, M., Yttri, K. E., Mihalopoulos, N., Kouvarakis, G., Beddows, D., Harrison, R.M., Cavalli, F., Putaud, J.P., Spindler, G., Wiedensohler, A., Alastuey, A., Pandolfi, M., Sellegri, K., Swietlicki, E.,
Jaffrezo, J.L., Baltensperger, U. and Laj, P. (2016). A European aerosol phenomenology-5: Climatology of black carbon optical properties at 9 regional background sites across Europe. Atmos. Environ. 145: 346-364. https://doi.org/10.1016/j.atmosenv.2016.09.035

Zhang, Q., Jimenez, J.L., Canagaratna, M.R., Allan, J.D., Coe, H., Ulbrich, I., Alfarra, M.R., Takami, A., Middlebrook, A.M., Sun, Y.L., Dzepina, K., Dunlea, E., Docherty, K., DeCarlo, P.F., Salcedo, D., Onasch, T., Jayne, J.T., Miyoshi, T., Shimono, A., Hatakeyama, S., Takegawa, N., Kondo, Y., Schneider, J., Drewnick, F., Borrmann, S., Weimer, S., Demerjian, K., Williams, P., Bower, K., Bahreini, R., Cottrell, L., Griffin, R.J., Rautiainen, J., Sun, J.Y., Zhang, Y.M. and Worsnop, D.R. (2007). Ubiquity and dominance of oxygenated species in organic aerosols in anthropogenically-influenced northern hemisphere midlatitudes. Geophys. Res. Lett. 34: L13801. https://doi.org/10.1029/2007GL029979

Zhang, R., Khalizov, A.F., Pagels, J., Zhang, D., Xue, H. and McMurry, P.H. (2008). Variability in morphology, hygroscopicity, and optical properties of soot aerosols during atmospheric processing. Proc. Natl. Acad. Sci. U.S.A. 105: 10291. https://doi.org/10.1073/pnas.080486 0105

Zhang, X., Lin, Y., Surratt, J. and Weber, R. (2013). Sources, composition and absorption angstrom exponent of light-absorbing organic components in aerosol extracts from the Los Angeles Basin. Environ. Sci. Technol. 47: 3685-3693. https://doi.org/10.1021/es305047b

Zhang, Y., Forrister, H., Liu, J., Dibb, J., Anderson, B., Schwarz, J.P., Perring, A.E., Jimenez, J.L., CampuzanoJost, P., Wang, Y., Nenes, A. and Weber, R. J. (2017). Top-of-atmosphere radiative forcing affected by brown carbon in the upper troposphere. Nat. Geosci. 10: 486489. https://doi.org/10.1038/ngeo2960

Zhang, Y., Kang, S., Gao, T., Schmale, J., Liu, Y., Zhang, W., Guo, J., Du, W., Hu, Z., Cui, X., and Sillanpää, M. (2019). Dissolved organic carbon in snow cover of the Chinese Altai Mountains, Central Asia: Concentrations, sources and light-absorption properties. Sci. Total Environ. 647: 1385-1397. https://doi.org/10.1016/j.scitotenv.2018. 07.417

Zotter, P., Herich, H., Gysel, M., El-Haddad, I., Zhang, Y., Močnik, G., Hüglin, C., Baltensperger, U., Szidat, S., and Prévôt, A.S.H. (2017). Evaluation of the absorption angstrom ngstrom exponents for traffic and wood burning in the Aethalometer-based source apportionment using radiocarbon measurements of ambient aerosol. Atmos. Chem. Phys. 17: 4229-4249. https://doi.org/10.5194/acp17-4229-2017

Received for review, March 2, 2020 Revised, September 21, 2020 Accepted, September 29, 2020 